\title{
Alimentação popular em São Paulo (1920 a 1950) - políticas públicas, discursos técnicos e práticas profissionais
}

Jaime Rodrigues ${ }^{1}$

RESUMO: $\bigcirc$ artigo discute a construção da idéia de alimentação popular nos meios intelectuais em São Paulo, na primeira metade do século XX. Para isso, reconstitui, como motivos da má alimentação, elementos do debate em torno da renda e da ignorância dos mais pobres. Identificado o problema, as propostas de intervenção e as políticas públicas concentraram-se em alguns setores, abordados neste trabalho: métodos para a formação de educadores sanitários aptos a atuar também na educação alimentar; campanhas de instrução popular e criação de novos lugares de aprendizado (além das escolas, os centros de saúde e os lares); merenda escolar e outras alternativas de alimentação nas escolas; e diagnósticos referentes ao conteúdo e à forma da alimentação dos operários. Traduzidas em discurso técnicocientíficos, as propostas e políticas implementadas na cidade deixaram indícios em documentação de suporte e tipologia variados (fotografias, cartilhas, cartazes, cadernetas de inquéritos e textos acadêmicos).

PALAVRAS-CHAVE: Alimentação. História social. Nutrição. Saúde pública.

ABSTRACT: This article discusses how the concept of "lower-class eating habits" came about and developed in the intellectual circles of São Paulo during the first half of the $20^{\text {th }}$ century. It starts by reconstructing the elements of the debate around the income and ignorance of the underprivileged as the main reasons behind their bad eating habits. Then, it looks at the focal points for interventions and public policies proposed by the government to deal with the problem thus identified, namely: training methods to produce sanitation counselors capable of offering dietary guidance as well; popular educational campaigns and new learning sites in addition to schools (e.g. healthcare centers and households); lunch and other means of offering food at schools; and diagnostic studies about food intake and eating habits among laborers. Because they were translated into technical and scientific language, the proposals and policies implemented in São Paulo left traces in a variety of supporting documents and media (photographs, primers, posters, inquiry notebooks, and academic literature).

KEYWORDS: Eating Habits. Nutrition. Social History. Public Health.
1. Docente da Universidade Federal de São Paulo - Campus Guarulhos - Filosofia e Ciências Humanas, Estrada do Caminho Velho 333, Bairro dos Pimentas, 07252-312, Guarulhos - SP. E-mail: $<$ jaime.rodrigues@unifesp. br $>$. Este trabalho integra as atividades do programa de pós-doutorado desenvolvido pelo autor na Faculdade de Saúde Pública da USP entre 2005 e 2007 , com apoio financeiro da FAPESP. 
2. Na definição do governo federal (2003-2006), segurança alimentar "é um conceito amplo que procura garantir o direito de acesso diário à alimentação, em quantidade, qualidade e regularidade suficientes a todo cidadão brasileiro, em especial aos mais pobres". Cf. <http://www. mds. gov.br/secretarias/secretaria 01_33.asp >, acessado em 9 jan. 2006. Para uma discussão do Programa Fome Zero do ponto de vista da Saúde Pública, ver Saúde e Sociedade v. 12, n. 1, jan.-jun. 2003 (número temático: Fome, Pobreza e Saúde Pública).

3. Segundo Walter Belik (2003, p. 14), trata-se de um conceito que "veio à luz a partir da Segunda Grande Guerra,com mais de metade da Europa devastada e sem condições de produzir o seu próprio alimento". O conceito levaria em conta os aspectos da quantidade, qualidade e regularidade no acesso aos alimentos. Em que pese a alegada antiguidade do conceito, a partir de 1945 não o encontrei sendo usado de forma re corrente na bibliografia brasileira acerca dos temas alimentares.
A alimentação, em roupagens variadas, está na ordem do dia no Brasil do século XXI. Certamente, muito desse interesse imediato reside no acompanhamento das políticas públicas emanadas especialmente do governo federal, a partir de 2003, quando da criação do Ministério do Desenvolvimento Social e Combate à Fome - em cujo organograma inserem-se a Secretaria de Segurança Alimentar e Nutricional (Sesan) e o Conselho Nacional de Segurança Alimentar e Nutricional (Consea), responsáveis pela implementação das ações nessa área ${ }^{2}$

Nas atuais políticas voltadas à segurança alimentar ${ }^{3}$, não se esboça nenhum traço de dúvida quando à razão da fome: trata-se de um problema decorrente da má distribuição de renda. A questão é pungente e encontra-se no fulcro das profundas divisões sociais existentes no país, sendo abordada de maneiras diferentes, caracterizando, ainda, a imagem do país, seja entre os brasileiros ou no exterior.

A unanimidade em torno da má distribuição de renda como motivo para a persistência da fome remete a um debate que atravessou quase todo o século XX. Refiro-me à discussão que opunha argumentos em torno de dois paradigmas, ou seja, a carência alimentar como resultado da ignorância da população ou como fruto dos baixos níveis de rendimentos da maioria da população. De que tipo seria a fome dos brasileiros? Qualitativa-protéica ou quantitativa-calórica? A abordagem nutricional não foi a única possível para se chegar a uma resposta, mesmo porque a Nutrição só veio a se constituir como campo do conhecimento vinculado às ciências da saúde no decorrer desse longo debate.

Analisadas em perspectiva histórica, a segurança alimentar e, de forma abrangente, a alimentação, revelam-se temas perseverantes - certamente, mais comuns no âmbito das políticas públicas e dos discursos de intelectuais ligados aos governos do que na produção dos cientistas sociais e historiadores brasileiros, como indicaram Meneses e Carneiro (1997, p. 52) e Santos (2005, p. 11-311.

A princípio, seria oportuno discutir as contribuições de autores que repuseram o tema da alimentação em foco, particularmente no âmbito dos estudos econômicos de caráter retrospectivo. Economistas que, em momentos diferentes de suas trajetórias profissionais, estiveram ligados a entidades sindicais e/ou ao governo produziram alguns textos cuja leitura deixa entrever a atualidade do assunto, a abordagem multidisciplinar das intervenções nessa área e a importância desses estudos para os profissionais que lidam com as questões da alimentação.

As metodologias de aferição, por equipes de economistas, dos padrões de vida de diferentes grupos sociais - como as Pesquisas de Orçamentos Familiares (POF) e as Pesquisas de Padrão de Vida (PPV) - revelam a importância do item "alimentação" nos gastos familiares ou individuais dos assalariados em temporalidades distintas, ao longo do século XX. De acordo com os técnicos do Departamento Intersindical de Estatística e Estudos Socioeconômicos (Dieese), os gastos de famílias operárias em São Paulo com o item "alimentação" teria caído de $64,3 \%$ (em 1958) para $51 \%$ do orçamento em 1970 (excetuadas as despesas 
com moradia), o que sinalizaria uma perda real do poder aquisitivo do salário mínimo (ARANTES, 2000, p. 185), mas, ainda assim, indicando que mais da metade das despesas familiares se destinava a suprir esse item fundamental da sobrevivência.

A partir do cruzamento de dados obtidos nessas pesquisas e da sua comparação com estudos consolidados de padrões nutricionais, pôde-se constatar que a renda era o fator decisivo na definição das possibilidades de desnutrição em amplos setores da população. Estudiosos ligados ao Instituto de Pesquisas Econômicas (atual Fundação Instituto de Pesquisas Econômicas da Universidade de São Paulo - FIPE-USP) coletaram dados junto a mais de 2.000 famílias paulistanas, entre setembro de 1971 e agosto de 1972, concluindo que uma parcela minoritária dos entrevistados $(15,7 \%)$ encontrava-se fora dos padrões nutricionais adequados. Também concluíram que, a partir de um nível de renda superior a um salário mínimo por pessoa, essa inadequação se tornava insignificante e que a deficiência alimentar era mais de quantidade do que de qualidade (ALVES, 1977, p. 145).

Se até aqui as conclusões não chegam a surpreender, a afirmação seguinte - de que o grau de educação formal dos pais influía de modo irrelevante na determinação do estado nutricional das famílias (ALVES, 1977) - levanta questões que permitem retomar as pretensões dos higienistas, médicos e nutrólogos que insistiam na ignorância popular em relação à alimentação e eram céticos quanto à salvação pública que decorreria dos programas de educação alimentar.

A insuficiência calórica (não vinculada à educação, e sim à renda) voltou a ser identificada na pesquisa promovida pelo Dieese em 1987, em 3 mil domicílios, a pedido do Instituto Nacional de Alimentação e Nutrição, órgão do Ministério da Saúde criado em 1972 e extinto em 1997. Para efeito de comparação, os pesquisadores valeram-se de outra pesquisa - feita pelo órgão em 1982, em 2 mil domicílios - tendo como público-alvo, nos dois casos, a população da cidade de São Paulo.

Embora próximas no tempo, as pesquisas revelavam conjunturas econômicas e situações de segurança alimentar bastante diferentes. Se em 19821983 a recessão era aguda, 1987 trazia em seu bojo uma nova crise, após o rápido crescimento econômico de 1985 - ano dos efeitos efêmeros do Plano Cruzado na estabilização monetária e na recomposição do poder aquisitivo dos assalariados. O agravamento da situação alimentar era evidente no intervalo entre as duas pesquisas: se na primeira (1982-1983), a situação era inadequada para $26,7 \%$ das famílias paulistanas, na segunda (1987), esse percentual subira para alarmantes $43 \%$. Ainda que a situação entre os trabalhadores fosse "desalentadora", como afirmaram os autores do estudo, nem por isso havia evidência "de que as famílias pobres são desnutridas porque não sabem comer" (BARELLI; ALVES; MARTINI, 1989, p. 75, 80).

Identificada a "situação nutricional não adequada" - ou "questão de segurança alimentar", se quiséssemos atualizar a expressão -, as propostas apresentadas situavam-se de forma privilegiada no campo da economia, mas não exclusivamente da renda. Na década de 1970, os economistas propunham 
4. Cf. Commemorative address by professor M. Cépède, Independent Chairman of athe FAO Council. Disponível em: <http://www.fao. org/docrep/x5591E/x5591e 0a.htm>, acessado em $3 \mathrm{fev}$ 2006. a criação de programas de distribuição de renda e geração de empregos, programas de cupons de alimentação e fornecimento de alimentos ou refeições subsidiadas, além de intervenção na cadeia de distribuição e comércio (ALVES, 1977, p. 145-146). No final da década seguinte, estudiosos da mesma linhagem intelectual insistiam na melhoria do poder aquisitivo como medida essencial, além de incentivos à produção de alimentos para consumo interno e apelos para que $O$ movimento sindical se organizasse e interviesse nos problemas de desnutrição e pobreza (BARELLl; ALVES; MARTINI, 1989, p. 81 ). Tais propostas certamente não soariam bem aos ouvidos dos arautos do agronegócio no Brasil do século XXI, conscientes da sua condição de astros da política econômica e propulsores do imenso superavit na balança de comércio exterior do país nos últimos anos.

Para os mais jovens, a discussão pode parecer ter surgido recentemente, o que não deve conduzir ao engano. Ressalto a importância do Relatório BurnetAykroyd, marco mundial na elaboração de políticas alimentares, e o embate de seus autores com as políiticas de desenvolvimento agrícola levadas a efeito em diferentes países. Tal relatório fora produzido no âmbito da Liga das Nações e divulgado em Genebra em 1936, recebendo oficialmente o sugestivo título de Nutrição e Saúde Pública. Nele, defendia-se a posição de que a pobreza era o fundamento da fome e da impossibilidade de muitas populações manterem-se saudáveis, apesar de economistas de peso alegarem que o mundo vivia uma situação de excesso de produção de alimentos. O relatório reconhecia a abundância produtiva, mas identificava como principal problema o baixo poder de consumo, defendendo a harmonização entre o desenvolvimento econômico e a promoção da saúde pública4.

Há décadas, portanto, os estudos econômicos sobre temas da alimentação apresentam um paradoxo. Afinal, preocupados com a composição e melhoria da renda dos trabalhadores, seus autores acabaram por introduzir na pauta de discussões o viés social - ou, ao menos, chamaram a atenção para a necessidade de uma abordagem que não privilegiasse o alimento apenas em seus aspectos econômicos (como mercadoria) ou fisiológicos (como necessidade humana básica). Hábitos, gostos, classe, origem nacional/regional, circuito produtivo e meio ambiente são aspectos importantes numa análise da alimentação em perspectiva histórica.

E é nessa perspectiva que, nas páginas a seguir, sugiro uma discussão sobre as políticas públicas, os discursos técnicos e as práticas de profissionais ligados à higiene e à saúde pública acerca da alimentação popular entre as décadas de 1920 e 1950. Nesses discursos e nessas práticas, ressaltei aqueles referentes à cidade de São Paulo, mas nem por isso a discussão das políticas públicas deixou de passar pelo âmbito da federação sempre que isso se mostrasse pertinente.

Em se tratando de um tema estudado em um período relativamente longo, penso ser conveniente indicar uma periodização que leve em conta mudanças e permanências nos discursos, nas políticas e nas práticas sobre a alimentação popular.

A primeira metade da década de 1920 foi uma época de adensamento das discussões sobre a alimentação. No caso de São Paulo, esse também foi o 
período em que o Instituto de Higiene passou a desempenhar um protagonismo na implementação de métodos de pesquisa e propostas de políticas públicas acerca das questões alimentares. Para o escopo deste trabalho, proponho iniciar a análise dos estudos e práticas higienistas ligados à alimentação dos paulistanos em 1923. Em outubro daquele ano, reuniu-se no Rio de Janeiro o I Congresso Brasileiro de Higiene. Nele, quatro dos vinte temas em debate referiam-se à alimentação: fiscalização sanitária dos gêneros alimentícios; abastecimento do leite; alimentação escolar e pré-escolar; e alimentação dos soldados brasileiros (ANAIS, 1926b, p. 99-138). Nesse congresso, quatro dos cinco representantes de São Paulo eram vinculados ao Instituto de Higiene (Geraldo Horácio de Paula Souza, Francisco Borges Vieira, Antonio de Almeida Júnior e Samuel B. Pessoa). Um desses representantes - Almeida Júnior - publicou, naquele mesmo ano, uma Cartilha de higiene para uso das escolas primárias (1923b), dando destaque às comidas e bebidas apropriadas às crianças em idade escolar.

A alimentação manteve-se como tema recorrente, e proporcionalmente relevante, nos encontros de higienistas. Em 1948, quando os membros do VII Congresso Brasileiro de Higiene se reuniram na Faculdade de Higiene e Saúde Pública, em São Paulo, a chamada "higiene alimentar" foi um dos quatro itens oficiais, ao lado da educação sanitária, da higiene rural e da epidemiologia e profilaxia (Cf. PROGRAMA; e LIVRO DE ASSINATURAS). Entre as décadas de 1920 e 1950, foram mantidos alguns dos temas consagrados de estudos alimentares (como a importância da educação escolar) e investiu-se em outros, relacionados às condições de produção, conservação e enriquecimento dos alimentos, a alimentação dos operários e a aplicação de inquéritos alimentares (em São Paulo, em 1932) e pesquisas de padrão de vida (especialmente entre os anos de 1937 e 1952).

Esses estudos e práticas dialogavam com a pesquisa acadêmica acerca da alimentação no âmbito da Higiene - campo do conhecimento em que se cruzavam ciências biológicas e sociais; e, também, conhecimentos relativos à educação. De acordo com Lima (1997, p. 27), o período entre 1934 e 1946 foi marcado pelo desenvolvimento de estudos pioneiros da nutrição no país. Curiosamente, a autora não se debruçou sobre os estudos antecedentes, escritos a partir dos anos 1920. Na definição dos marcos temporais, Lima também não levou em conta o curso de nutricionistas, criado em 1939 e ministrado no Instituto de Higiene ${ }^{5}$, sendo reformulado em 1946. A autora definiu o período entre 1940 e 1946 como o da reordenação do conhecimento adquirido (LIMA, 1997, p. 2718), delineando-se o objeto da nutrição por um viés marcadamente fisiológico, o que revela a dificuldade enfrentada na luta para garantir ao conhecimento nutricional o caráter de disciplina autônoma em relação à medicina e à higiene. Os vínculos da nutrição com as ciências sociais sofreram uma ruptura acentuada.

ano de 1946, marco final da periodização de Lima, foi também aquele em que começou a funcionar o primeiro curso de graduação em nutrição no país, na Universidade do Brasil (Rio de Janeiro). No mesmo ano, alterou-se o curso existente no antigo Instituto de Higiene, transformando-o em curso anexo para formação de nutricionistas da Faculdade de Higiene e Saúde Pública da
5. Cf. decreto 10617 , de 24 de outubro de 1939 . 
6. Nos termos dos decretos 15 549-A, de 15 de janeiro de 1946 (aprova o Regulamento da Faculdade de Higiene e Saúde Pública da Universidade de São Paulo) e 15553 de 24 de janeiro de 1946 (aprova o Regulamento do Curso de Nutricionistas)
Universidade de São Pauló. Se até então se vivia a reordenação do conhecimento, a partir daí tratava-se de aplicar o que já tomara contornos de ciência. A institucionalização do ensino, o método científico da nutrição e sua aplicabilidade social não passaram desapercebidos por olhares atentos na época, como o do chargista Belmonte (Figura 1).

Práticas profissionais representadas em imagens

Algumas das fotografias feitas por profissionais do Instituto de Higiene na primeira metade da década de 1920 (VASCONCELLOS, 1995; e RODRIGUES; VASCONCELLOS, 2006) estão entre as práticas discursivas que podem ser apontadas como fontes para a história da alimentação em São Paulo, na primeira

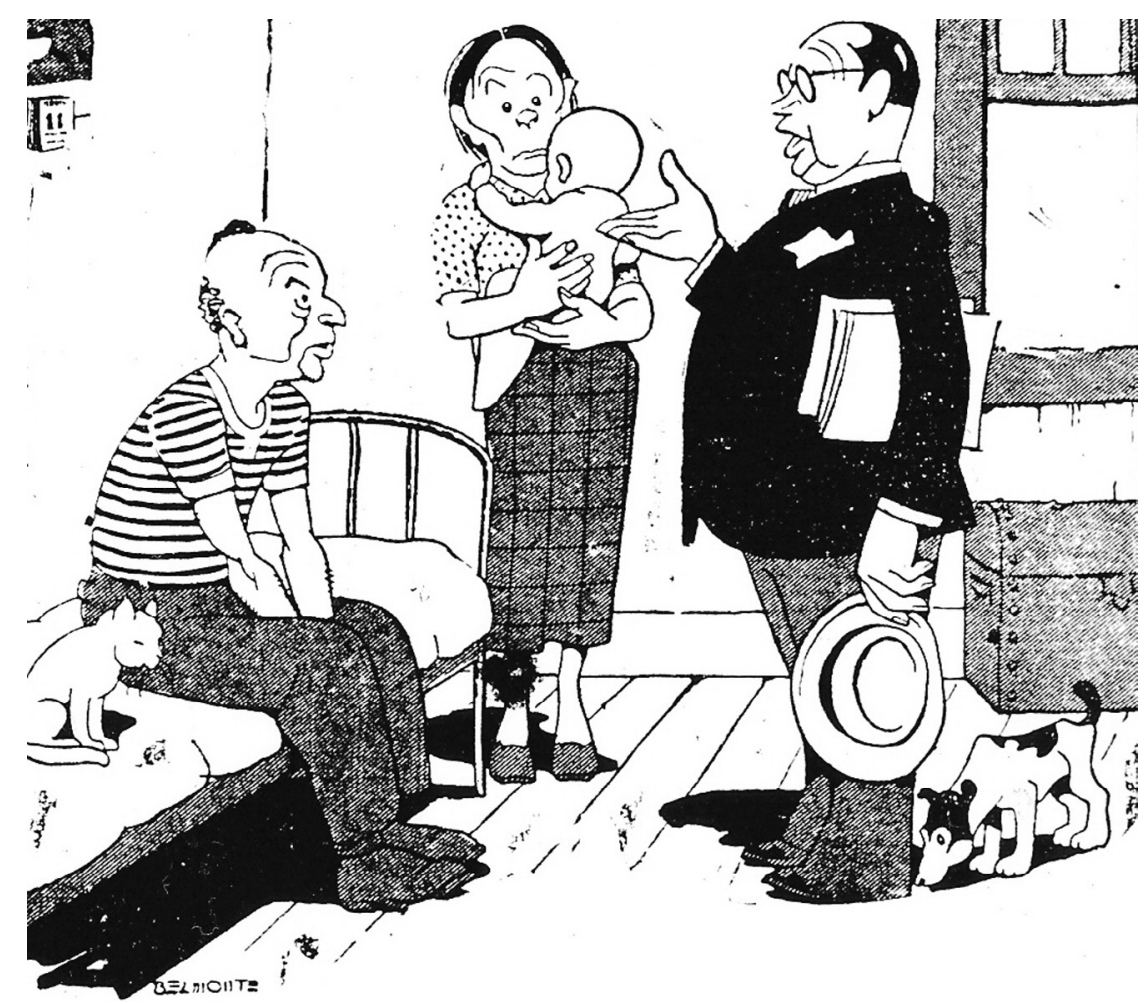

Figura 1 - Em 11 de abril de 1946, a Folha da Noite publicava charge de Benedito Bastos Tigre, que usava o pseudônimo de Belmonte. No alto, o texto informava sobre a abertura das inscrições para o curso de nutrição da Universidade do Brasil. No diálogo, o "nutrólogo", de paletó e gravata, tinha seus pés cheirados por um vira-lata e, impassível no ambiente de uma moradia pobre, afirmava, do alto de seu saber científico: "- Você precisa aprender a se alimentar. Deve ingerir ovos, carne, legumes, queijo, leite, cremes...". A mãe, com expressão estupefata pelo que ouvia, enquanto o "pobre diabo", pai de família, aparentando certo cansaço ou talvez tédio diante da visita do "nutrólogo", expressava o sentimento de sua família diante de palavras de tal gabarito: "E essas coisas existem?". Charge sobre o curso de médicos nutrólogos do Instituto de Nutrição da Universidade do Brasil. Imagem n. 1859, sem título, sem data, s.n.p. Acervo do Centro de Memória da Saúde Pública, Faculdade da Saúde Pública da USP, São Paulo. 
metade do século XX. Mostrada como cenário da modernidade nos cartões postais que circulavam na época, a cidade - 587 mil habitantes em 19207-era observada com outros olhos pelos higienistas e apresentava-se como campo privilegiado para as ações dos profissionais da saúde pública.

Partindo de um acervo que reúne imagens feitas em diferentes expedições higienistas, em áreas distintas da cidade, o Instituto produziu o álbum Vistas de São Paulo e do Instituto de Higiene, composto de 30 ampliações em papel fotográfico de $21 \times 16,5 \mathrm{~cm}$ (integrante do acervo do Centro de Memória da Saúde Pública, Faculdade de Saúde Pública-USP, doravante CMSP, Álbum 4). Nesse álbum (e em outras fotografias do mesmo período produzidas no Instituto), o olhar esquadrinhador dos editores-higienistas inseriu imagens propagandísticas de órgãos e profissionais vinculados à administração pública, mas concentrou-se na denúncia das más condições de abastecimento e alimentação oferecidas aos paulistanos na época (Figuras 2, 3 e 4).

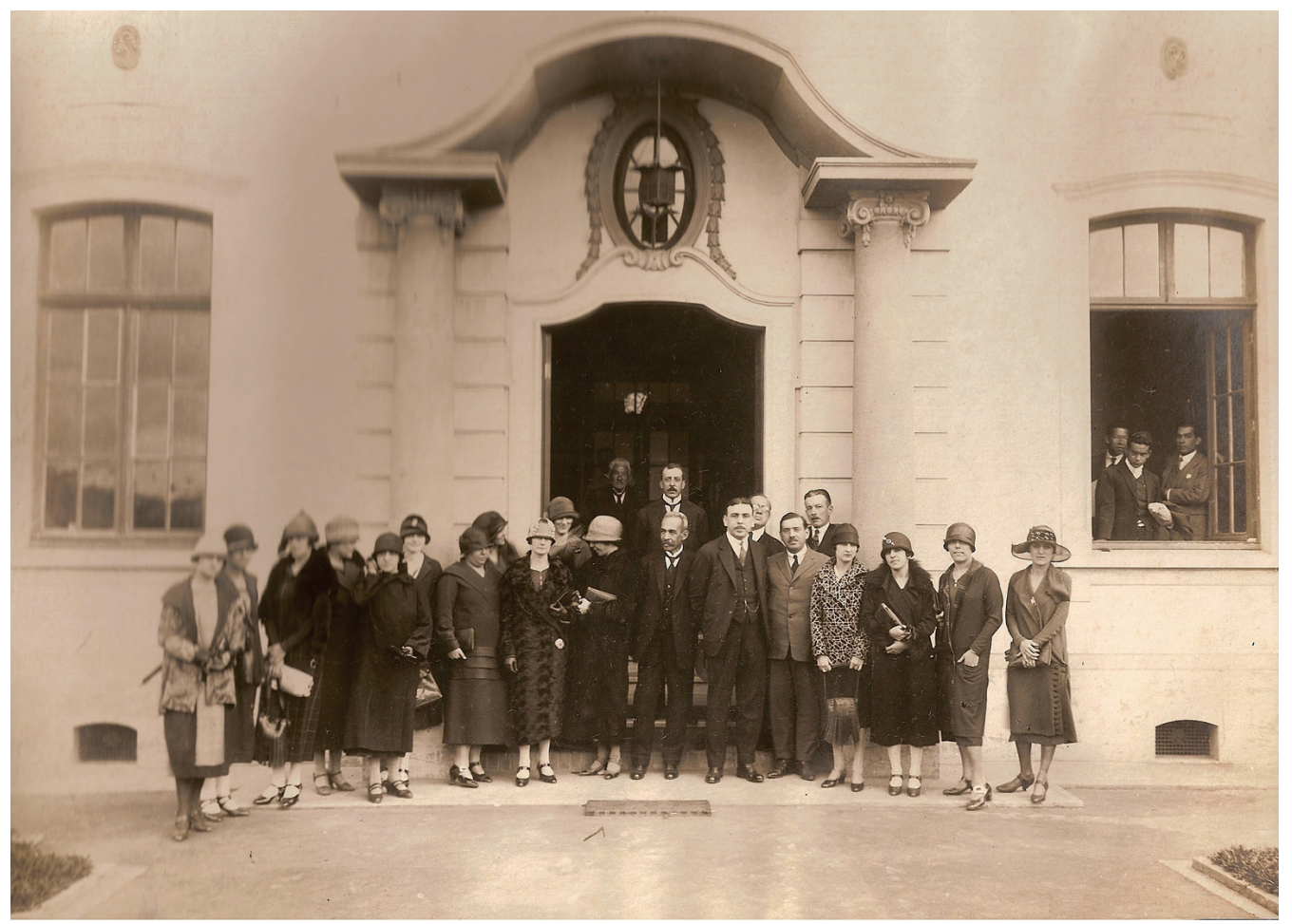

Figura 2 - Imagens do Serviço de Alimentação Pública. Na primeira foto, de acordo com a ordem do álbum, valorizam-se os recursos humanos /ainda que a legenda identifique poucos componentes da cena, entre eles Valdomiro de Oliveira, Costa Júnior, Adelino Leal, Davi Cavalheiro Barros Barreto e Antonieta Mendes de Castro). As imagens seguintes podem ser entendidas como demonstrações da capacidade do Estado em prover um serviço dessa natureza das instalações e dos equipamentos necessários para a ação, destacando a fachada bem conservada do edifício e os automóveis prontos para o uso estacionados defronte ao prédio. Em um deles podemos ver um ocupante aparentemente a postos para cumprir missão de trabalho assim que recebesse a ordem. Álbum de Vistas de São Paulo e do Instituto de Higiene (n.4), p. 14, década de 1920. Acervo do Centro de Memória da Saúde Pública, Faculdade da Saúde Pública da USP, São Paulo.
7. Cf. IBGE (1986, p. 8). Desse total, $35 \%$ eram estrangeiros, principalmente portugueses, italianos e espanhóis. Cf. Samuel H. Lowrie (1938, p. 196). 


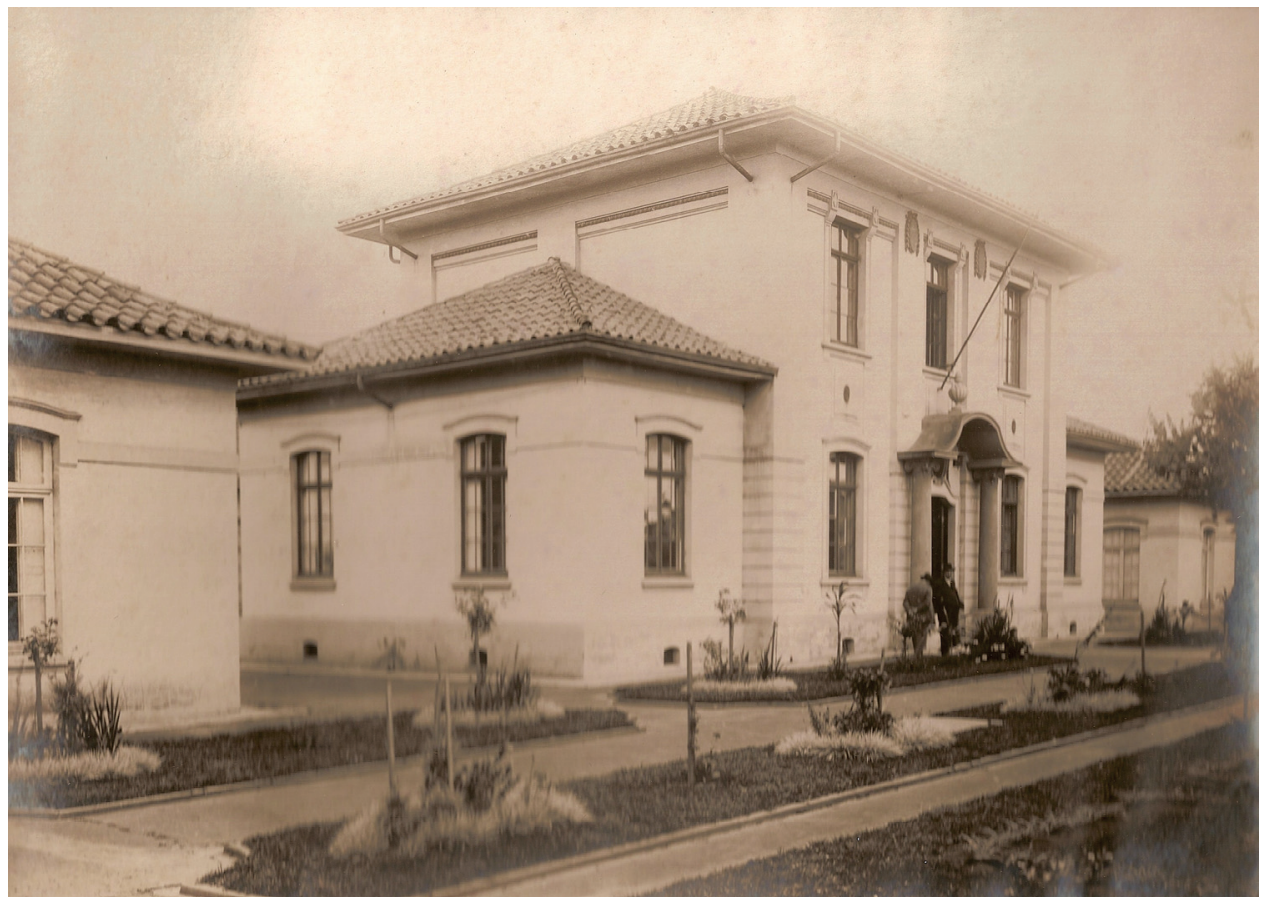

Figura 3 - Álbum de Vistas de São Paulo e do Instituto de Higiene (n.4), p. 15, década de 1920. Acervo do Centro de Memória da Saúde Pública, Faculdade da Saúde Pública da USP, São Paulo.

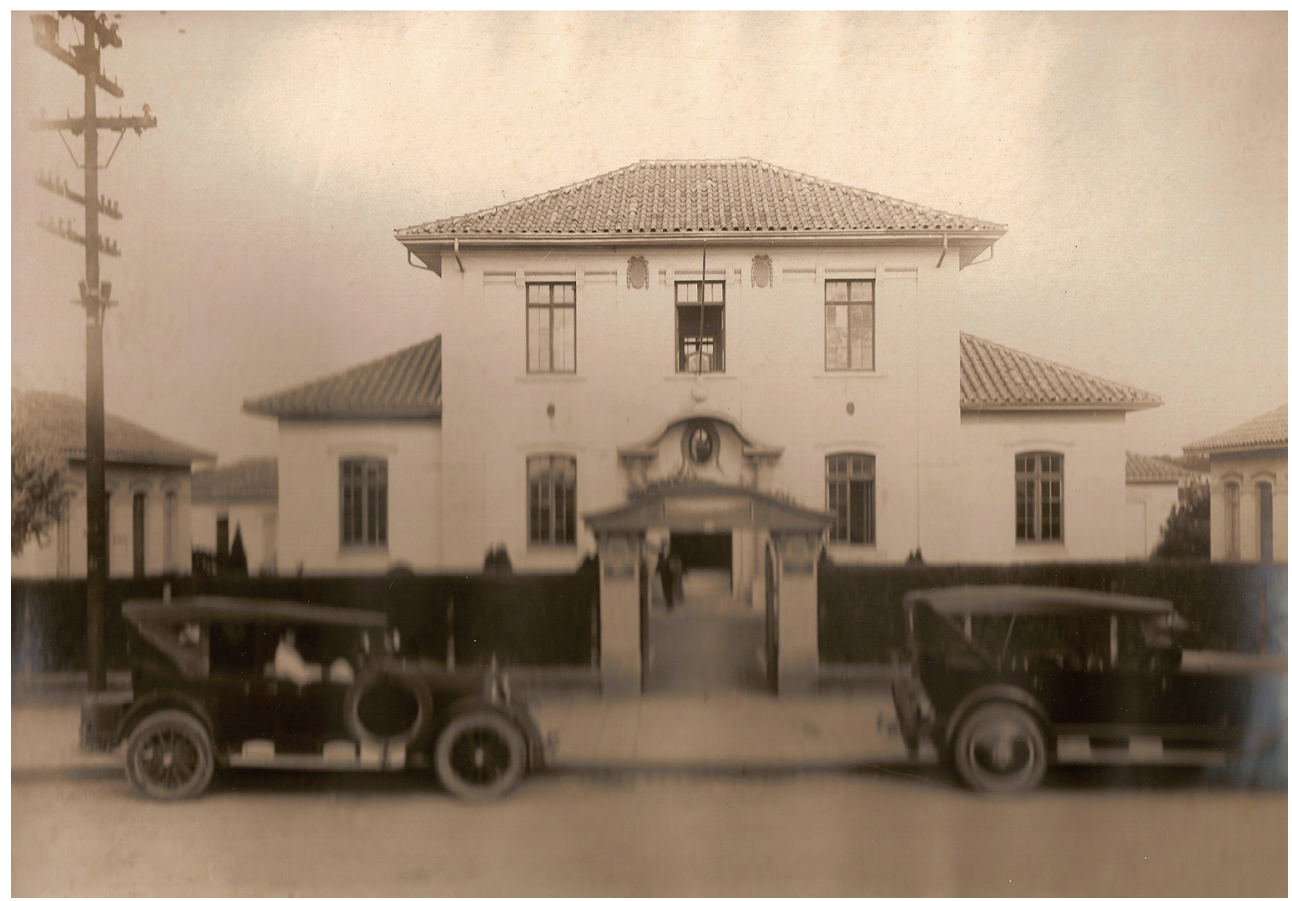

Figura 4 - Álbum de Vistas de São Paulo e do Instituto de Higiene (n.4), p. 16, década de 1920. Acervo do Centro de Memória da Saúde Pública, Faculdade da Saúde Pública da USP, São Paulo. 
Outras imagens que compõem esse álbum dizem respeito às tarefas de fiscalização do abastecimento alimentar. Feiras e mercados não passaram desapercebidos, sendo registrados - "pela lente da higiene", na expressão emprestada de Campos (2001) - os comerciantes e o público que acorriam diariamente a lugares como esses para prover suas despensas domésticas (Figuras 5 a 10).

Segundo afirmamos em trabalho já citado (RODRIGUES; VASCONCELLOS, 2006), a fotografia manteve uma relação profunda com as práticas higienistas, especialmente no período em que estas últimas estavam sendo gestadas no Instituto de Higiene, em São Paulo. A produção de imagens fotográficas era inerente aos métodos de identificação das condições em que as doenças proliferavam (neste caso, tanto nas cidades como no campo).

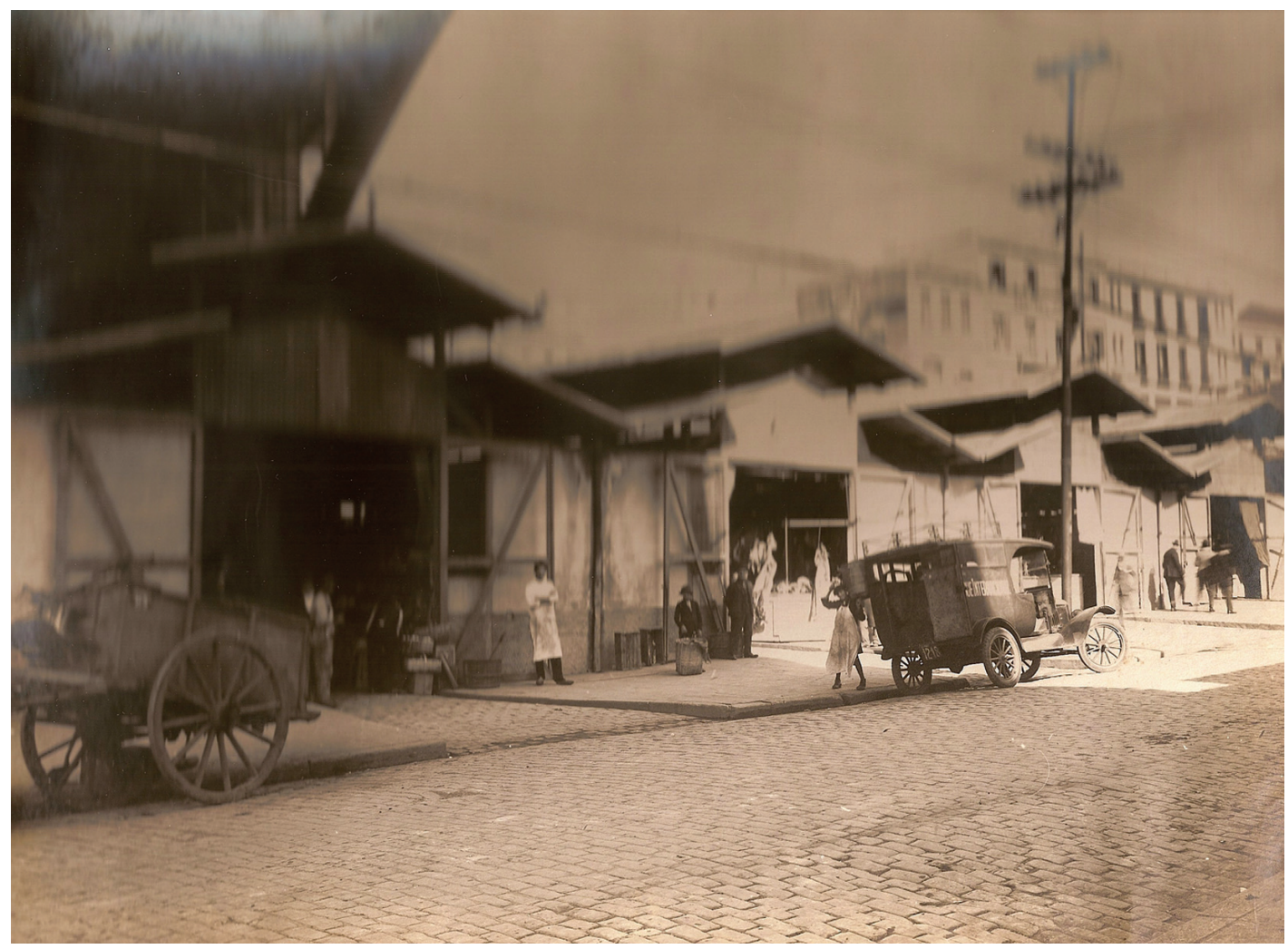

Figura 5 - Nesta seqüência, o olhar vai do geral ao particular. A primeira imagem, "Mercadinho nos baixos do Viaduto Sta. Efigênia", mostra o entorno da área do mercado (extinto após a inauguração do Mercado Municipal da Cantareira, em 19331, enquanto as demais nos transportam para o interior dos boxes de comerciantes. A senhora que vendia frutas aprovou visivelmente a feitura da foto, sorrindo para o fotógrafo, talvez orgulhosa pela disposição bem organizada dos produtos em seu comércio. Também parecem expressar satisfação os sorrisos indisfarçáveis do garoto e do senhor que está ao seu lado no açougue do mercadinho, onde as carnes (não sabemos se secas) eram expostas aos potenciais compradores fora de ambientes frigoríficos. Álbum de Vistas de São Paulo e do Instituto de Higiene (n.4), p. 12, década de 1920. Acervo do Centro de Memória da Saúde Pública, Faculdade da Saúde Pública da USP, São Paulo. 


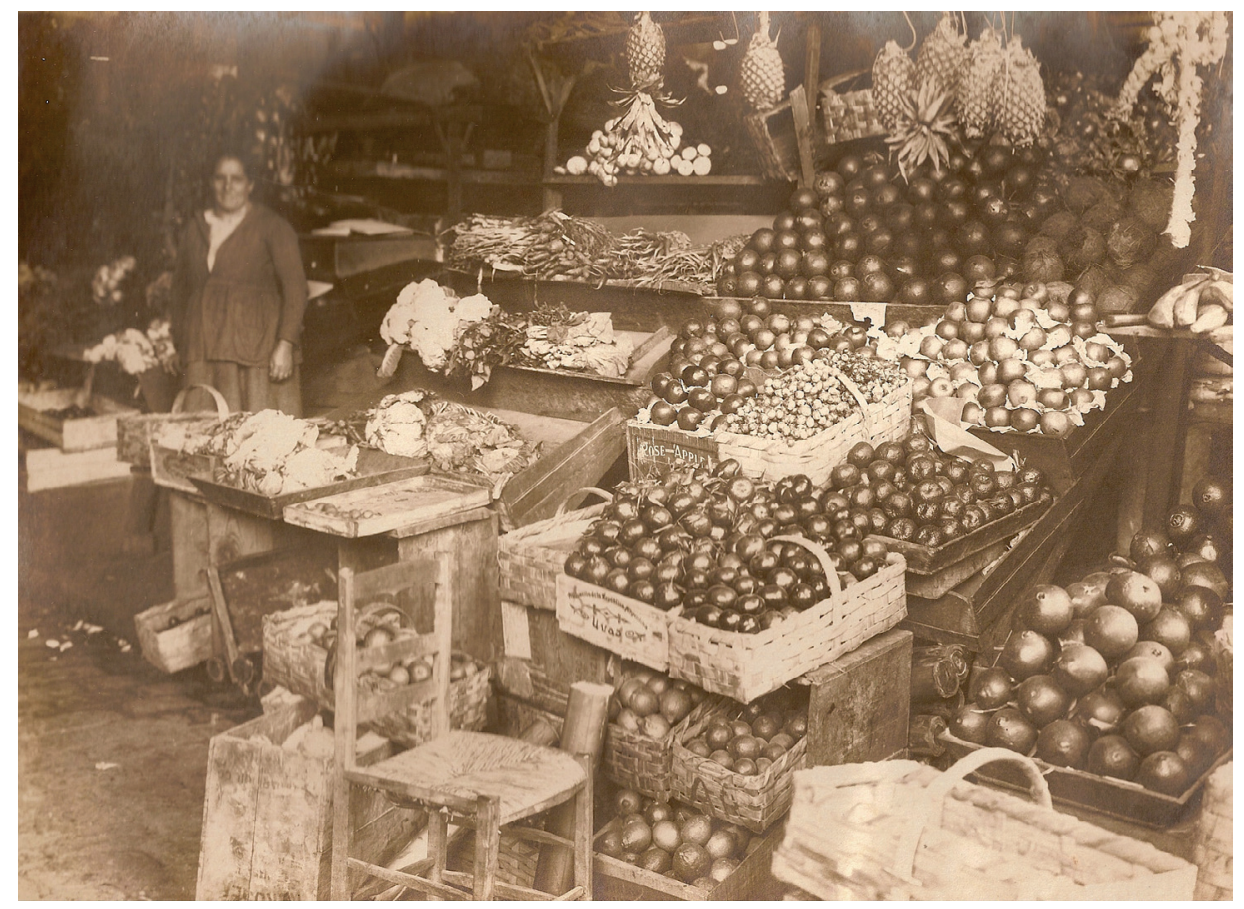

Figura 6 - Álbum de Vistas de São Paulo e do Instituto de Higiene (n.4), p. 17, década de 1920. Acervo do Centro de Memória da Saúde Pública, Faculdade da Saúde Pública da USP, São Paulo.

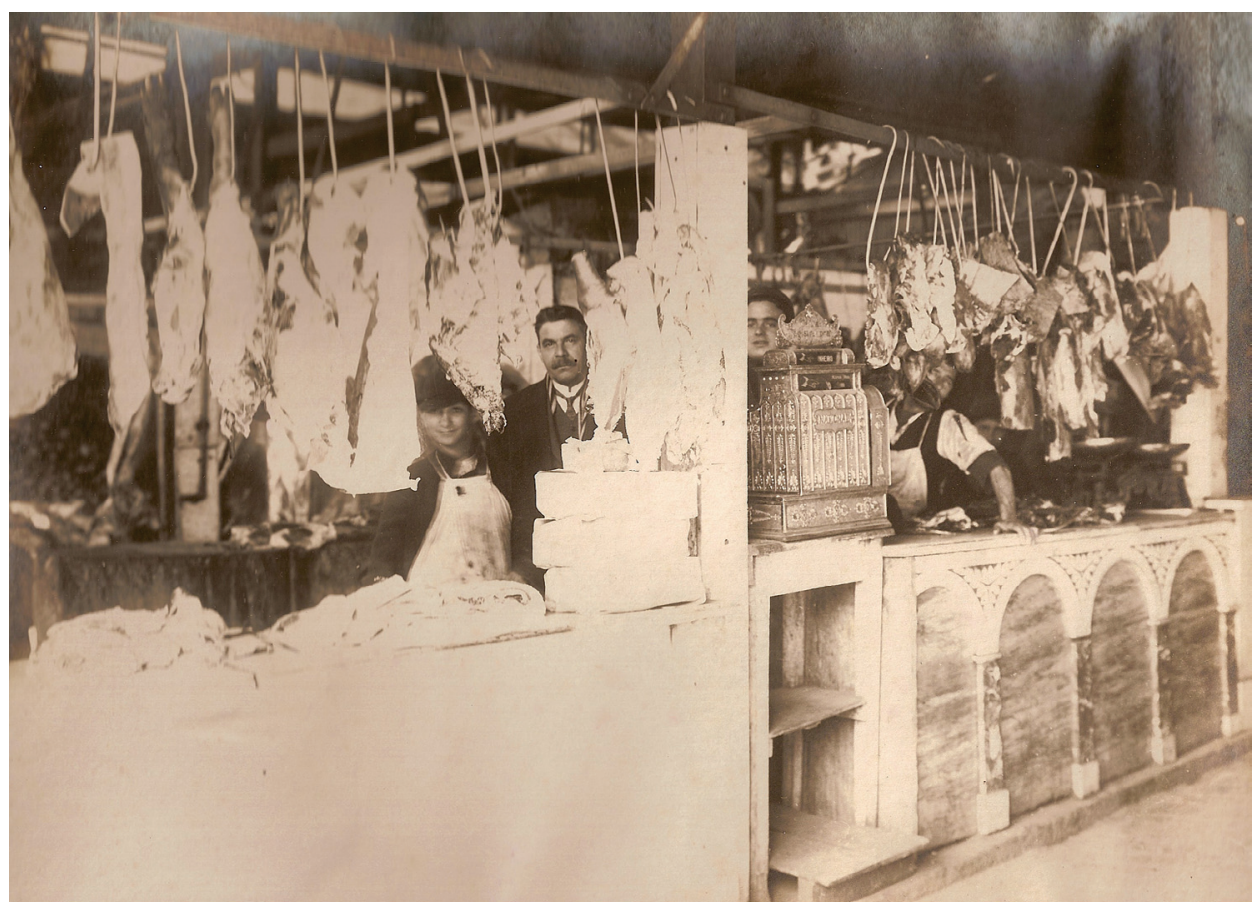

Figura 7 - Álbum de Vistas de São Paulo e do Instituto de Higiene (n.4), p.20, década de 1920. Acervo do Centro de Memória da Saúde Pública, Faculdade da Saúde Pública da USP, São Paulo. 


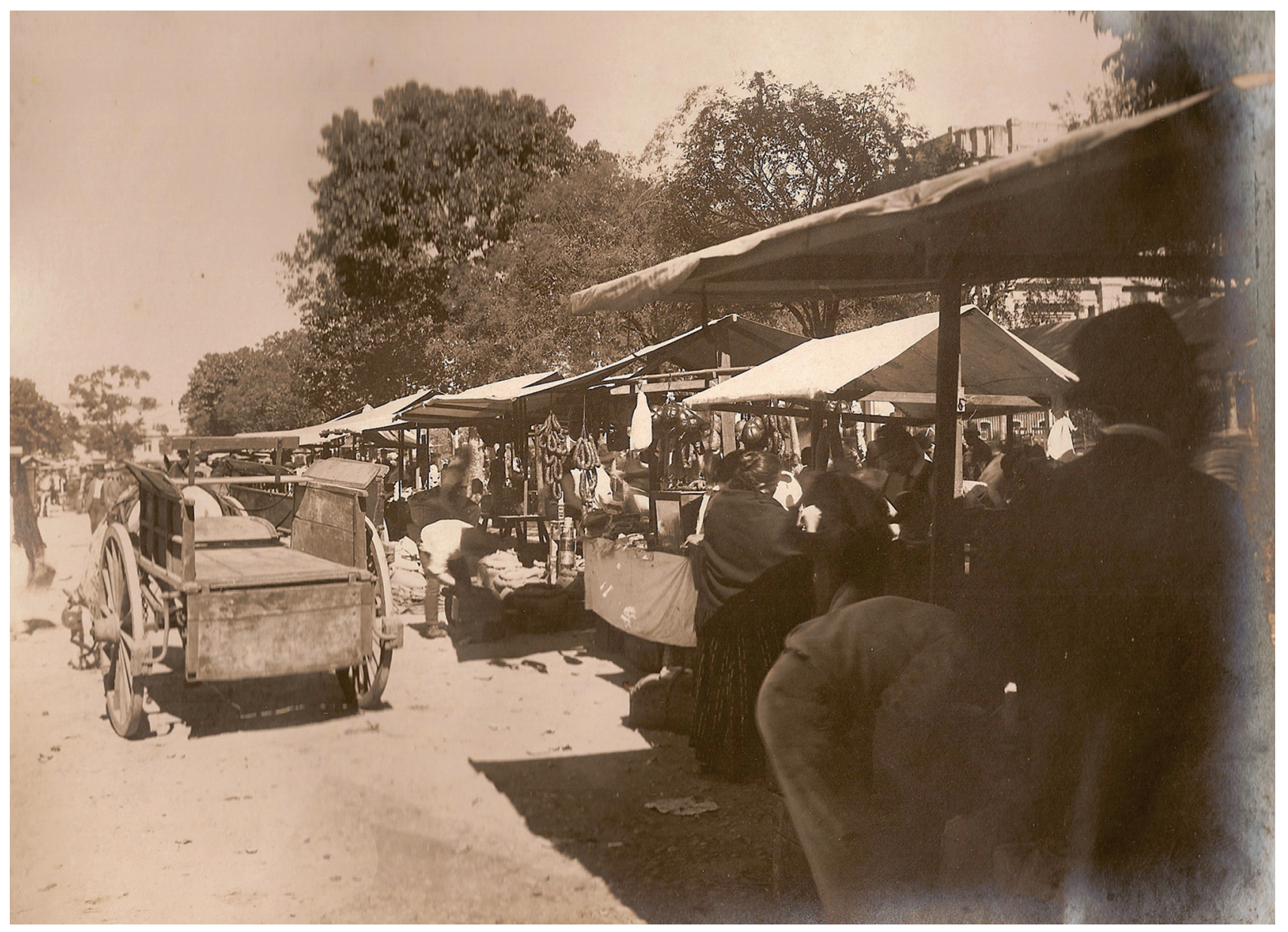

Figura 8 - Na primeira imagem, as coberturas das barracas tornam o ambiente bastante semelhante ao das atuais feiras-livres paulistanas - não fosse pela carroça de tração animal, provavelmente usada para o transporte de gêneros pelos feirantes ou pelos produtores que abasteciam o mercado. Mesmo aqueles comerciantes que não estavam ligados diretamente ao abastecimento alimentar eram alvo do olhar higienizador - como o do vendedor de louças, vidros, estatuetas e peças diversas -, provavelmente devido ao cigarro que trazia à boca em plena feira. $O$ sortimento de verduras, aparentemente menor do que o de frutas, mostra esses produtos de forma bem menos vistosa nas barracas, o que pode se dever a uma peculiaridade sazonal da época em que a foto foi feita. Álbum de Vistas de São Paulo e do Instituto de Higiene (n.4), p. 18, década de 1920. Acervo do Centro de Memória da Saúde Pública, Faculdade da Saúde Pública da USP, São Paulo. 


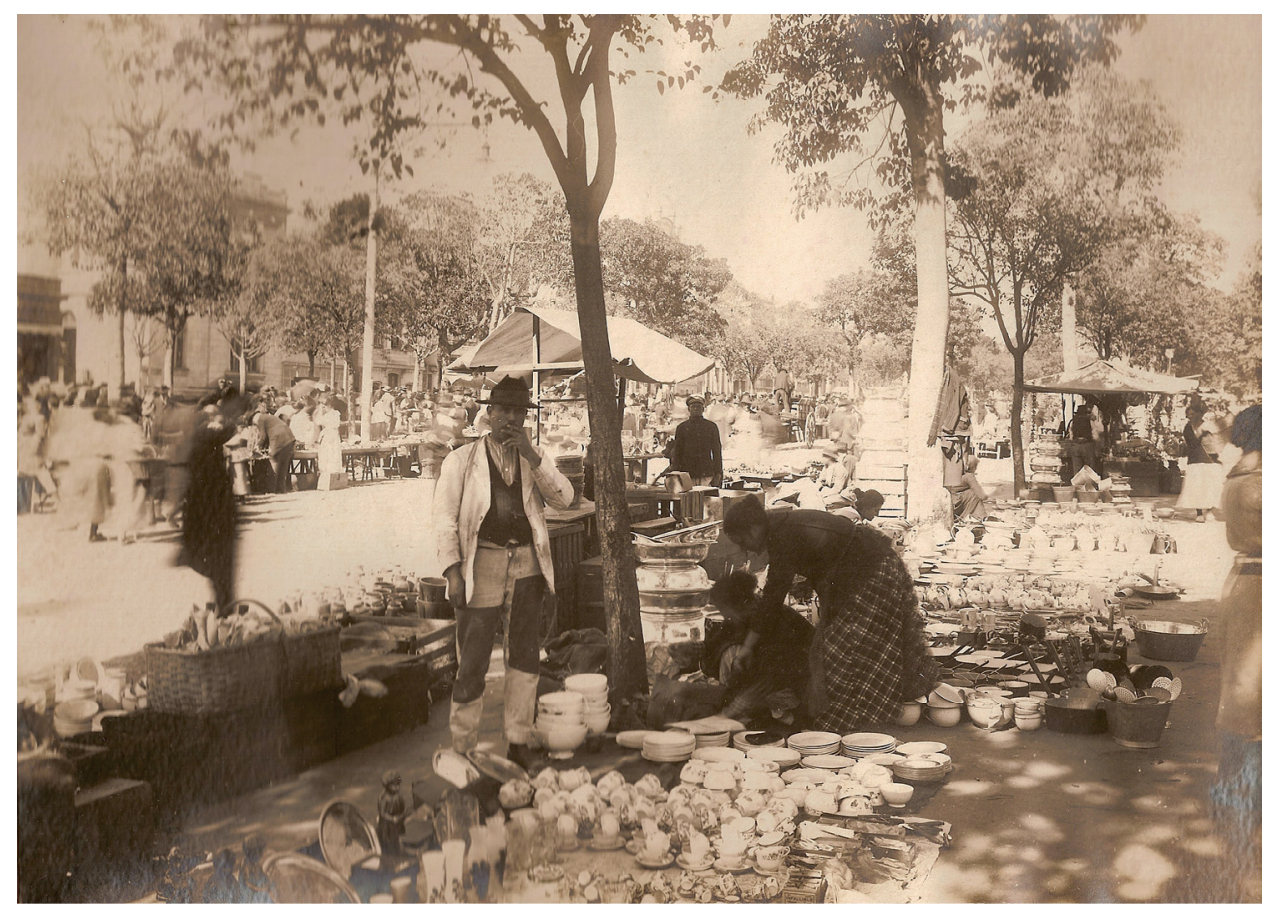

Figura 9 - Álbum de Vistas de São Paulo e do Instituto de Higiene (n.4), p.27, década de 1920. Acervo do Centro de Memória da Saúde Pública, Faculdade da Saúde Pública da USP, São Paulo.

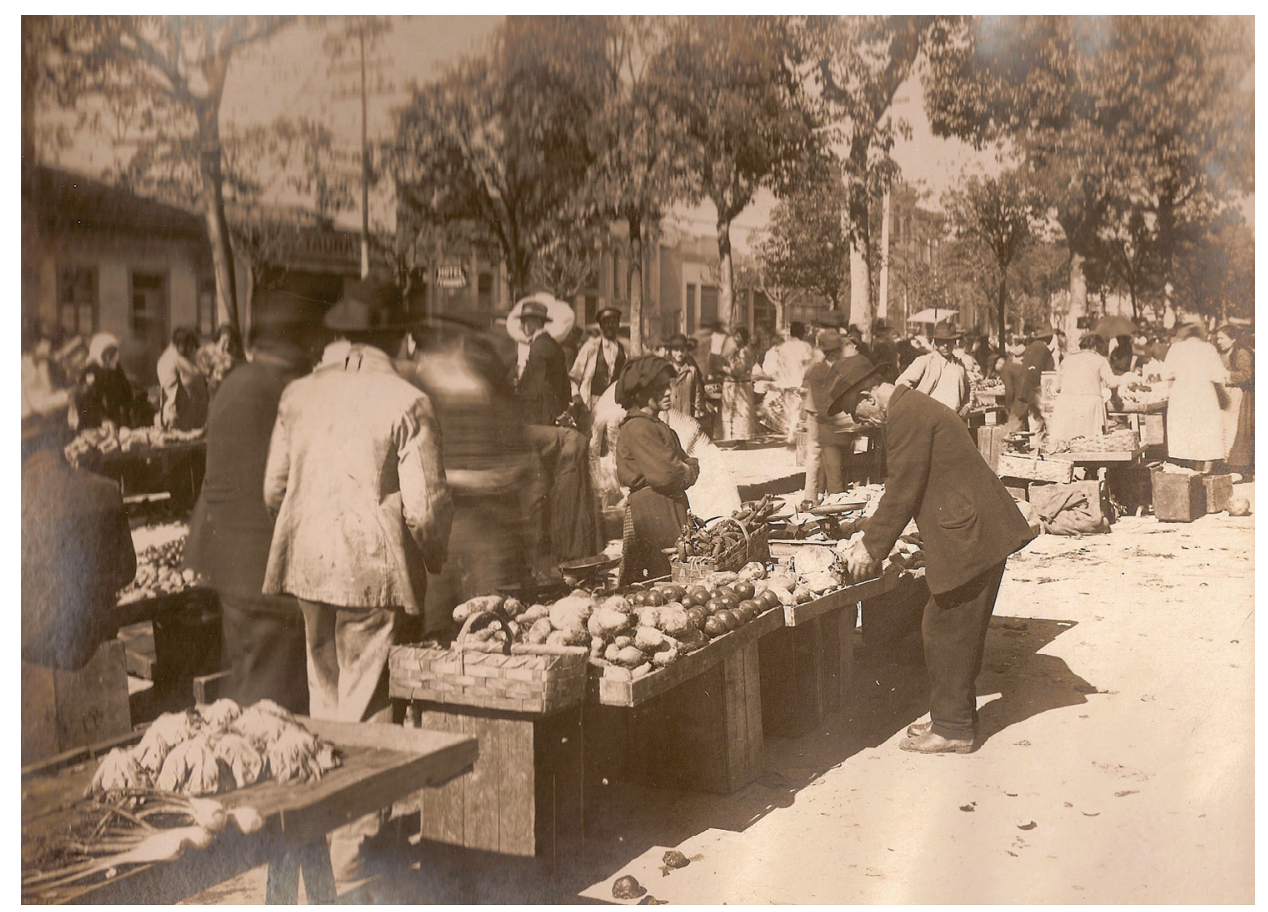

Figura 10 - Álbum de Vistas de São Paulo e do Instituto de Higiene (n.4), p.28, década de 1920. Acervo do Centro de Memória da Saúde Pública, Faculdade da Saúde Pública da USP, São Paulo. 
Ao longo dos anos 1920, profissionais e alunos do Instituto de Higiene conduziram centenas de inspeções sanitárias em localidades paulistas, com farto uso de fotografias ${ }^{8}$. Tal uso sugere que as imagens captadas pela técnica fotográfica, pela sua força e pela possibilidade de reproduzi-las, serviam aos objetivos dos higienistas em pelo menos dois aspectos complementares. Primeiramente, como instrumento de denúncia e prova documental considerada irrecusável, que os habilitava a propor intervenções higiênicas junto ao poder público. As imagens sugerem também o uso do objeto fotográfico como recurso pedagógico na formação de profissionais da higiene. As fotografias /o olhar do fotógrafo, melhor dizendo) carregavam mensagens subliminares acerca da necessidade de reconhecer o poder do higienista como formulador de políticas públicas nas áreas de saúde e planejamento urbano. Analisá-las requer o desenvolvimento de uma sensibilidade frente às imagens, atentando para a relação entre o fotógrafo e os "objetos" fotografados (GRANGEIRO, 2000, p. 1 17-1321 - especialmente quando estes eram moradores da cidade apanhados em situações de flagrante miséria.

Não há registros explícitos acerca dos critérios que presidiram a escolha das imagens do álbum Vistas de São Paulo e do Instituto de Higiene. Entretanto, a edição não parece ter descartado nenhum dos possíveis usos da fotografia entre os higienistas. Além das fotos aqui selecionadas para discutir o tema da alimentação popular, o álbum compilou imagens de crianças em atividade escolar, registros de atividades no centro de saúde localizado na primeira sede do Instituto de Higienea, laboratórios de veterinária, vistas do Jardim da Luz e do entorno, instituições como o Quartel da Força Pública e o Butantã, e problemas de infra-estrutura urbana que poderiam tornar-se objetos de intervenção dos higienistas - como alagamentos, falta de pavimentação e depósitos de lixo.

\section{que ensinar nas escolas}

As primeiras políticas públicas de alimentação propostas em São Paulo apresentavam-se estreitamente vinculadas às questões biológicas e sociais. Isso se expressava em estudos pioneiros, como a análise dos dados de inquéritos alimentares conduzidos a partir do Instituto de Higiene: "As questões atinentes à alimentação, merecendo estudo especial tanto de biólogos como de médicos e higienistas, pelas suas relações com a economia e o bem estar gerais, constituem problemas higiênicos-sociais da maior relevância" (SOUZA; CINTRA; CARVALHO, 1935, p. 31.

O vínculo entre higiene e educação pode ser exemplificado na análise da já mencionada Cartilha de Higiene, de Almeida Junior. Nela, havia restrições relacionadas às gulodices entre as refeições, ao café, aos chás e às bebidas alcoólicas para as crianças. $\bigcirc$ autor da Cartilha empenhou-se neste último item, fazendo afirmações contundentes para o imaginário infantil: "o filho do beberrão
8. Ver CMSP, Arquivo Geraldo Horácio de Paula Sou$z a$, documentos MI s/d 24, MI 1925.5, PI $1926.2 \mathrm{~A}$ e PI 1926.2B.

9. Na Rua Brigadeiro Tobias, n. ${ }^{\circ}$ 45. Só em 1933 ocorreu a transferência para a sede definitiva (na avenida Municipal, em frente ao Cemitério do Araçá).Ali funciona, atualmente, a Faculdade de Saúde Pública da Universidade de São Paulo, sucessora do antigo Instituto de Higiene e da Faculdade de Higiene e Saúde Pública, na rebatizada avenida Doutor Arnaldo. 
nasce fraco e doentio, quando não nasce idiota. Para as crianças, o álcool é um veneno perigoso. Os pais que dão álcool aos filhos cometem um crime". Entre as "oito regras de ouro" da higiene, o autor dedicava duas à alimentação: o consumo de verduras e frutas; e a ingestão de leite no lugar de café ou chá.

Um dos itens da Cartilha de Higiene intitulava-se "a boa alimentação" e ensinava o que se devia, ou não, comer, com farto uso de ilustrações e nível de linguagem textual acessível a crianças em idade de alfabetização (Figuras 11 e 12).

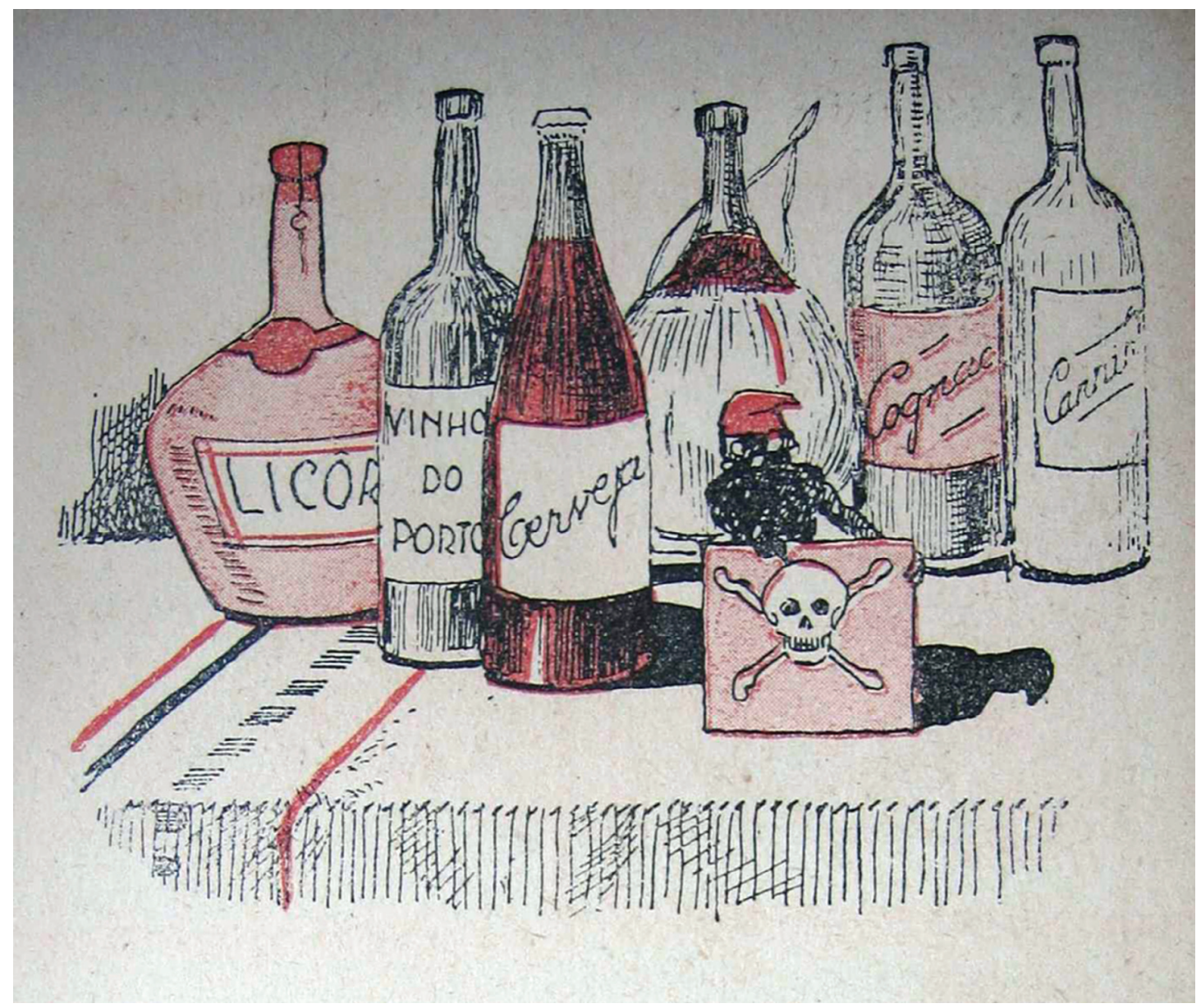

Figura 11 - A imagem do saci-pererê, difundida no imaginário das histórias infantis, era um recurso para atrair a atenção das crianças. A personagem estava presente em várias outras ilustrações da Cartilha e, neste caso, segurava o símbolo da morte e apontava em direção a ele, sinalizando o risco que as crianças corriam se consumissem bebidas alcoólicas. Entre as garrafas, destaco a presença de uma de vinho do Porto, reconhecido popularmente como fortificante para adultos e crianças, especialmente se misturado a gemas de ovos na feitura de gemadas. Reprodução de ilustração publicada na Cartilha de higiene para uso das escolas primárias, de Almeida Junior (1923b, p.23). Acervo do Centro de Memória da Saúde Pública, Faculdade da Saúde Pública da USP, São Paulo. 


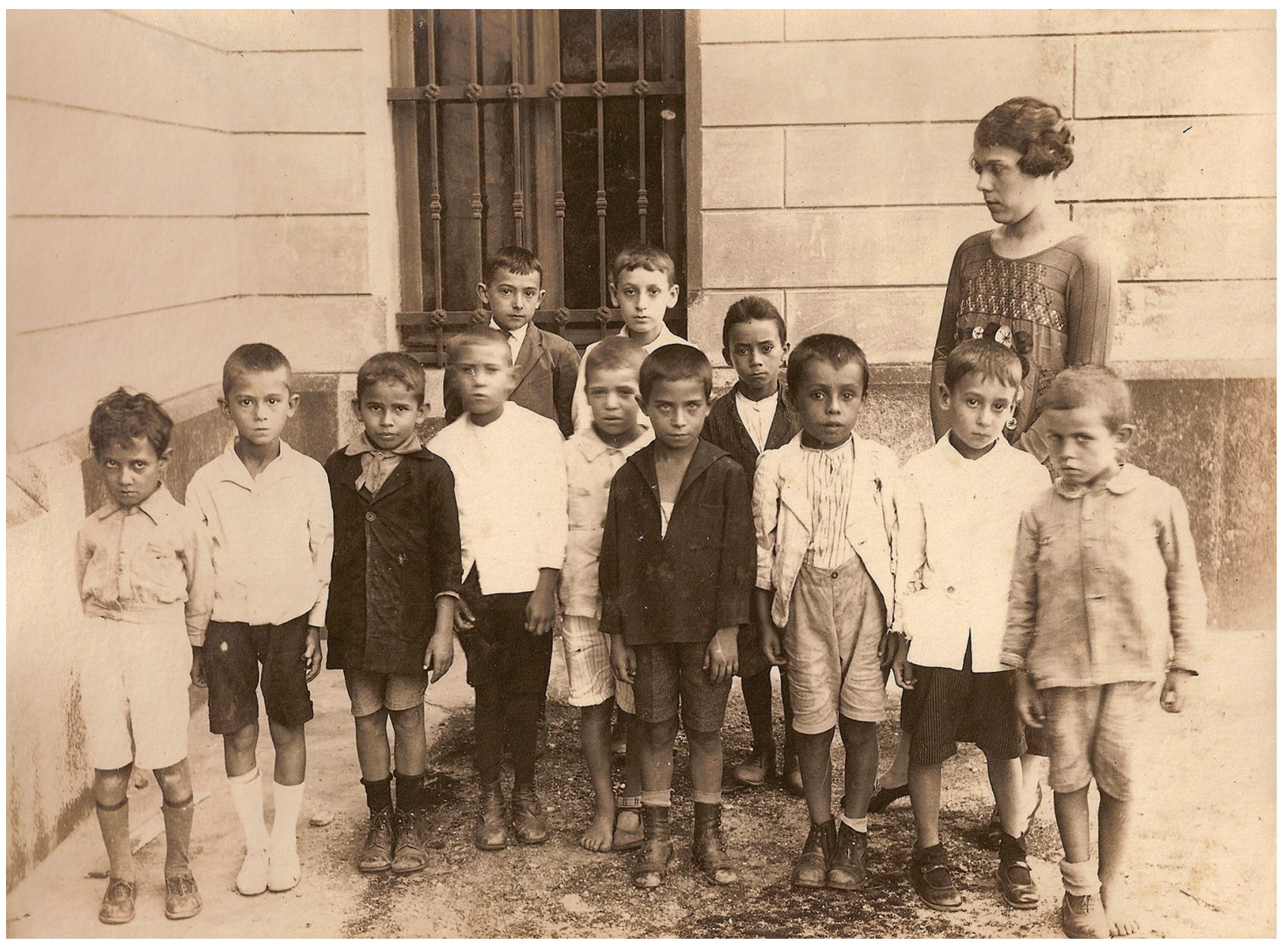

Figura 12 - "Alunos desnutridos", fotografia feita em uma escola não identificada em São Paulo (20\% abaixo da tabela do Dr. Vieira de Mello). Imagem n. 1751, sem título, sem data, s.n.p. Acervo do Centro de Memória da Saúde Pública, Faculdade da Saúde Pública da USP, São Paulo. seguinte inventário:

Na categoria da "boa alimentação", as crianças encontravam o

Feijão e arroz bem cozidos. / Verduras e frutas maduras. / Pão de trigo, de centeio, de milho. / Carne, só uma vez por dia. / Leite, manteiga, ovos, queijo. / Peixe muito fresco. / Alimentos duros, que dêem trabalho aos dentes: crosta de pão, frutas, nozes.

Na seqüência, a lista do que deviam evitar:

Comer muito. / Comer depressa, sem mastigar. / Comer estando cansado ou agitado. / Abusar da carne ou dos ovos. / Comer frutas verdes. / Comer alimentos muito engordurados. / Usar pimenta e outros temperos fortes. / Comer ou beber cousas muito quentes ou geladas (ALMEIDA JUNIOR, 1923b, p. 17-18). 
À primeira vista, os inventários da boa e da má alimentação podem nos parecer obviedades. Todavia, eles foram considerados importantes o suficiente para serem inseridos em um material de uso corrente nas escolas, num período em que o ensino formal em São Paulo dava os primeiros passos na direção da universalização - ou, ao menos, da extensão a um número maior de crianças, sinalizada pela expressiva quantidade de escolas construídas no estado ao longo da Primeira República (PEIRÃO et al., 1991). A inserção de dados referentes ao que as crianças deveriam ou não ingerir nos diz muito a respeito de como obviedades do mundo contemporâneo são construções históricas enraizadas no tempo.

A lista dos bons alimentos traz alguns conselhos que eventualmente podem nos soar estranhos - como a importância de se cozinhar bem os grãos, de consumir manteiga, nozes e pães feitos a partir de ingredientes como o milho. As nozes, certamente, não eram item comum nos cardápios do público que tinha acesso à Cartilha. Já a pimenta e outros condimentos talvez o fossem, e a interdição desses ingredientes na comida das crianças pode ser entendida como um esforço para padronizar hábitos alimentares oriundos das colônias estrangeiras - como sírios e espanhóis, por exemplo, numerosos na cidade do começo do século XX - ou remanescentes da época colonial, em que as especiarias compunham os pratos e educavam os gostos alimentares (LIMA, 1999; TAKASU, 2000; LORIMER, 20011 .

A relação das interdições incluía não só tipos de alimentos, mas também comportamentos. Se os primeiros conselhos eram úteis principalmente para a manutenção da disciplina no ambiente escolar (comer pouco, com vagar e descansado), os ensinamentos referentes ao álcool eram claramente voltados aos adultos das famílias. Os pais que davam bebidas alcoólicas aos filhos eram chamados de criminosos - o que, inserido em uma cartilha escolar, aponta para uma prática que talvez fosse freqüente. Pais pouco cuidadosos e higienistas perscrutadores, ao que tudo indica, são personagens de uma história bastante antiga (Figuras 13, 14 e 15).

Almeida Junior tornou-se um especialista na questão alimentar dos escolares. A publicação de sua Cartilha precedeu até mesmo a implantação, em 1925, do primeiro curso de Educadores Sanitários, que tinha como objetivo fazer "a divulgação de noções de higiene para alunos das escolas primárias estaduais" (MASCARENHAS; FREITAS, 1959, p. 243). Além da Cartilha, a produção acadêmica de Almeida Junior também esteve voltada para a temática da alimentação popular, atribuindo pouco empenho aos homens de governo e cientistas em relação às pesquisas nutricionais. Ao Estado cabia aparelhar as instituições voltadas a essas pesquisas, já que "a ciência da nutrição não se faz nos gabinetes, ou em laboratórios improvisados com parcimônia e modéstia" (ALMEIDA JUNIOR, 1923a, p. 3). Quanto aos cientistas, deviam conduzir as pesquisas empíricas e fazer sentir o peso de seu conhecimento, retirando a alimentação do âmbito da "politicagem de aldeia" e da ação dos curiosos que davam palpites descabidos sobre alimentos e dietas: 
De vez em quando, surgem advogados da abóbora, apóstolos do limão, cavaleiros andantes da cebola, apontando os seus ídolos como exclusivos merecedores de nosso culto e dos nossos dentes. E os ídolos, repentinamente, mergulham no esquecimento. Não se diga que estas paixões alimentares medram apenas entre os profanos: pesados livros de ciência consignam tais exageros e perpetuam as dissensões românticas entre a carne e o vegetal, entre o jejum e a abundância (ALMEIDA JUNIOR, 1923a, p. 3).

autor provavelmente dialogava com as informações estampadas nos jornais e nas revistas ilustradas, profusos em anúncios sobre o poder miraculoso de certos alimentos, e também em matérias (pagas ou não), veiculadas a mando de médicos (ou supostos profissionais da medicina e da nutrição), que divulgavam soluções mirabolantes para problemas de saúde baseados em dietas também mirabolantes. Nesse sentido, a primeira metade do século XX e o início do século XXI guardam profunda semelhança entre si - épocas em que a oferta de soluções rápidas e eficientes encontra ressonância no público consumidor de fórmulas dessa natureza, especialmente no que se refere ao emagrecimento feminino, ou

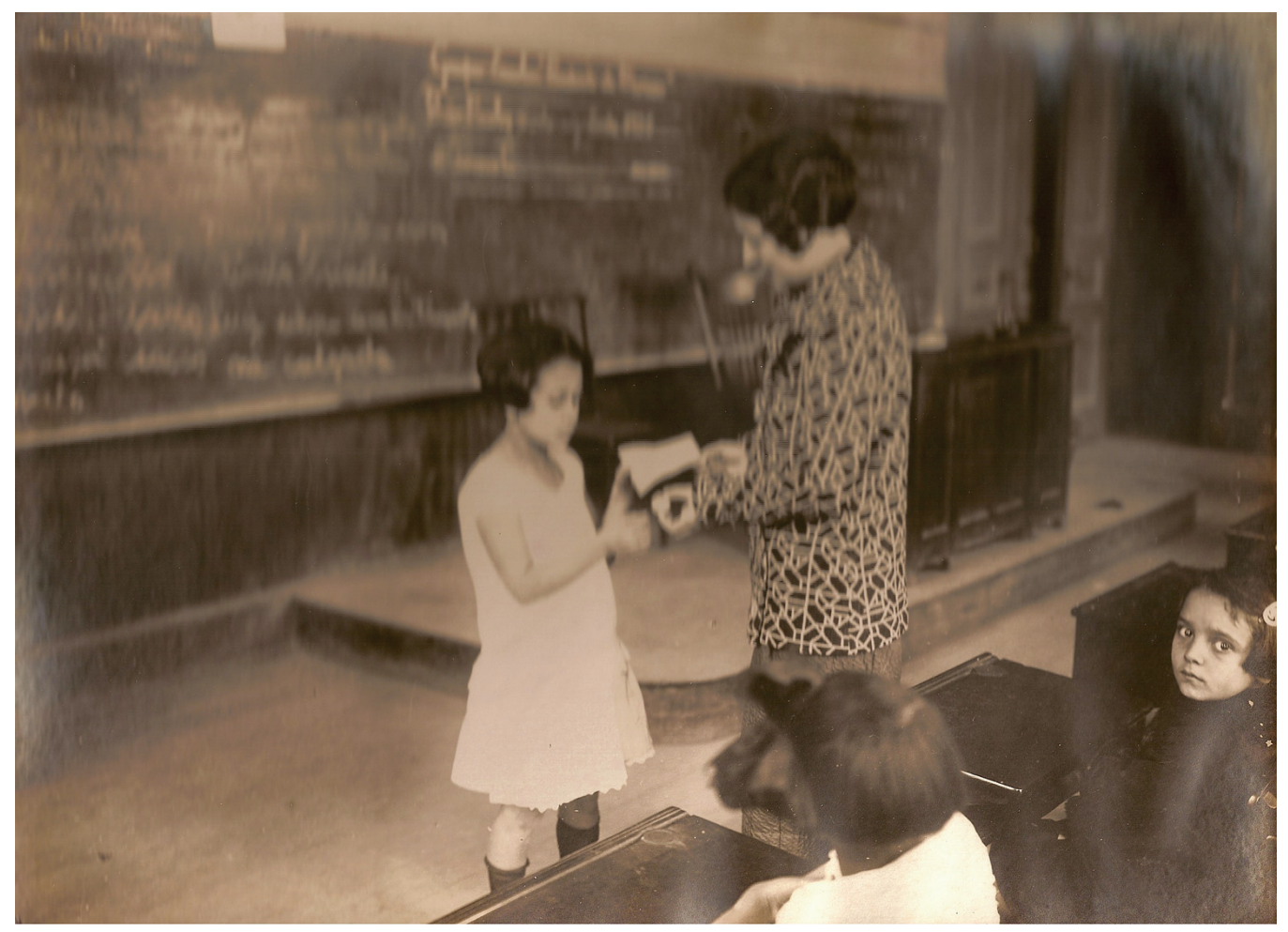

Figura 13 - Classes femininas em aulas de educação sanitária, nas quais a Cartilha e outros ensinamentos higiênicos foram potencialmente ministrados. Leituras, observações em equipamentos inusitados para o ensino nessa fase (como o microscópio) e atividades lúdicas eram alguns recursos dos quais as educadoras se valiam para transmitir noções de higiene, fruto da prática profissional delas e da formação adquirida no Instituto de Higiene. Educação em saúde na Escola Prudente de Morais (Bairro da Luz). Álbum de Vistas de São Paulo e do Instituto de Higiene (n.4), p.4, 1925. Acervo do Centro de Memória da Saúde Pública, Faculdade da Saúde Pública da USP, São Paulo. 


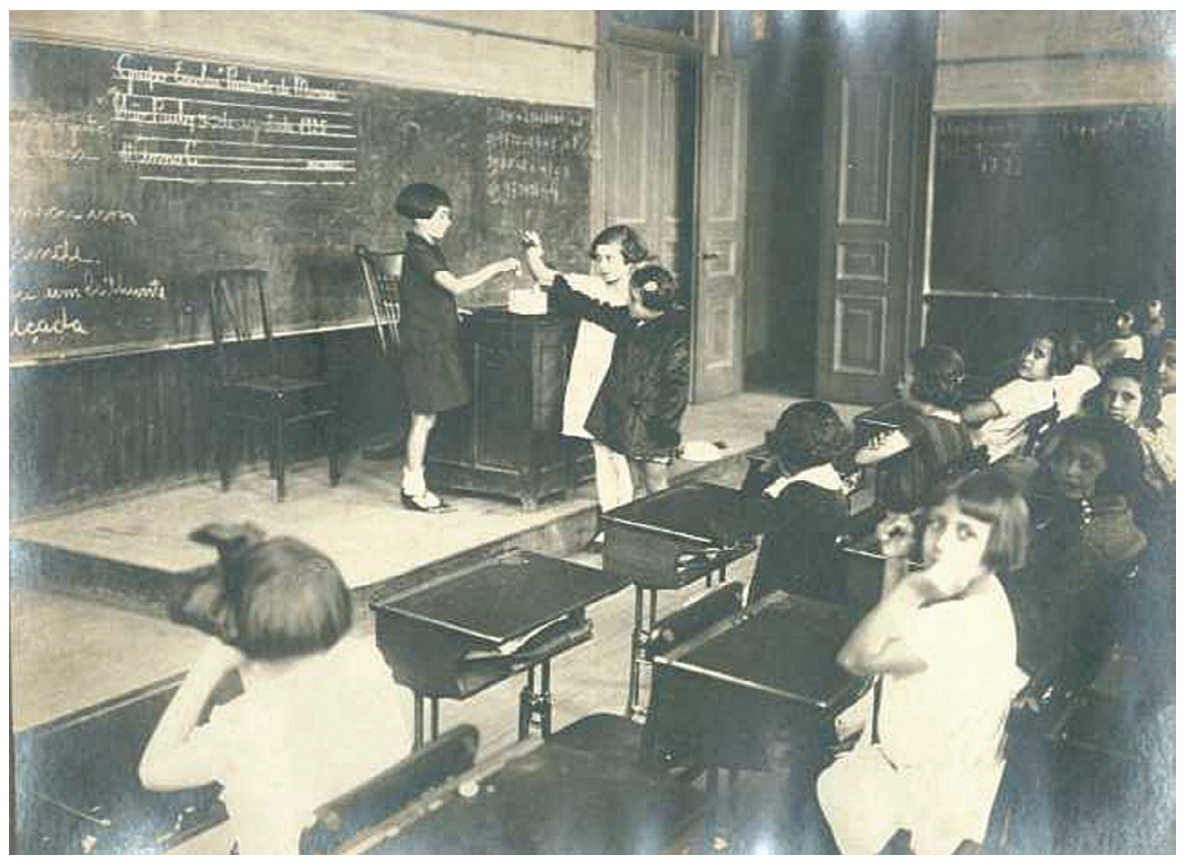

Figura 14 - Educação em saúde na Escola Prudente de Morais (Bairro da Luz). Imagem n. 1792, sem título, 1925, s.n.p. Acervo do Centro de Memória da Saúde Pública, Faculdade da Saúde Pública da USP, São Paulo.

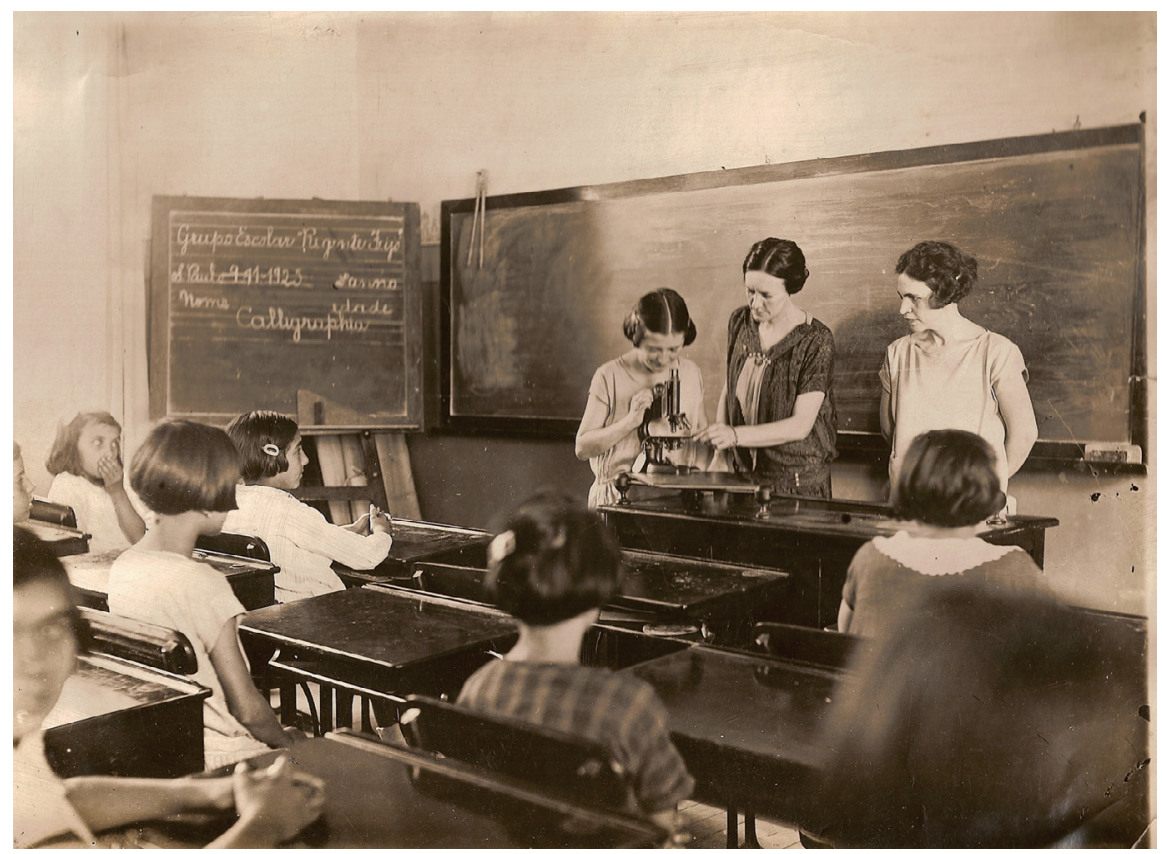

Figura 15 - Educação sanitária, Grupo Escolar Regente Feijó latual Escola Estadual Teodoro de Moraes, bairro Água Rasa). Imagem n. 1722, sem título, 9 de novembro de 1925, s.n.p. Acervo do Centro de Memória da Saúde Pública, Faculdade da Saúde Pública da USP, São Paulo. 
à criação de massa muscular entre os homens, para adequar-se a mutantes padrões de beleza.

A principal intenção de Almeida Junior não era debater com charlatães, mas sim dar bons conselhos aos responsáveis por crianças na faixa etária que ia do fim da amamentação até o início da adolescência lem que o leite deixava de ser o alimento exclusivo e a dieta passava a ser predominantemente sólida). $\bigcirc$ crescimento do corpo e a atividade física faziam com que o gasto de energia fosse bastante ampliado nessa fase. Era aí, também, que se podia incutir nas crianças, e nos púberes, hábitos (o bem) ou vícios (o mal) que passariam a ser adotados pela vida afora:

a escolha dos alimentos, o horário das refeições, os cuidados de asseio, a mastigação, a digestão, a própria evacuação intestinal [...]. É comum encontrarem-se crianças que detestam - leite, que abominam a carne, que não toleram as verduras [...]. Afora os possíveis casos de idiossincrasias, parece que se trata, as mais das vezes, de vício adquirido na infância, evitável por uma educação bem conduzida [...]. A educação higiênica é igualmente o melhor fator para difundir o uso de alimentação mais sensata entre as classes populares, ensinando-thes as vantagens da variedade, as virtudes de certos alimentos como o leite e as verduras [...] e tantas outras pequenas cousas, já sabidas na higiene alimentar (ALMEIDA JUNIOR, 1923a, p. 4-7).

A "higiene alimentar" continuaria embutida na formação de educadoras sanitárias após a reforma curricular de 1946, que regularizou a duração do curso em um ano, dividido em quatro períodos, e manteve a disciplina no segundo período dos cursos da Faculdade de Higiene e Saúde Pública ${ }^{10}$, agora sob a responsabilidade do recém-instituído Departamento de Nutrição.

Instrução popular

Na opinião de Jurandir Freire Costa, diferentes agentes do Estado, desde o período colonial, empenhavam-se em reduzir a autonomia das famílias e, em nome do saber técnico, deslocar a responsabilidade dos adultos leigos para os especialistas. Já nessa época, as concepções médicas acerca da alimentação entendiam existir uma ignorância dos pais, ao prescreverem a alimentação mais adequada à família colonial como forma de garantir a interiorização dos hábitos europeus no Brasil (COSTA, 1979).

Talvez não precisemos ir tão longe e nem concordar integralmente com as afirmações do autor, mas, em linhas gerais, esse raciocínio nos leva a querer saber mais sobre outros períodos da história do Brasil nos quais as tentativas de técnicos e cientistas para impor um saber hegemônico foram mais incisivas. A visão das classes populares como ignorantes e pouco cuidadosas em relação às suas práticas, aos seus hábitos e comportamentos alimentares pode ser percebida em muitos estudos realizados no século XX, quando o Estado já se
10. Cf. decreto 15552 , de 24 de janeiro de 1946 (aprova o Regulamento do Curso de Educadores Sanitários da Faculdade de Higiene e Saúde Pública da Universidade de São Paulo). 
instrumentalizara melhor para intervir - situação que, se for projetada para a época colonial, requer cuidados redobrados.

A necessidade de "difundir o uso de alimentação mais sensata entre as classes populares", como argumentava Almeida Junior em 1923, certamente tinha antecedentes. Como o propósito aqui não é refazer a genealogia dessa preocupação, analisarei alguns estudos dos intelectuais que levaram essa noção adiante, até pelo menos os meados do século XX.

Inicialmente, convêm definir o que vem a ser ignorância. Um primeiro sentido para o termo poderia ser a impossibilidade, dos consumidores, de escapar de fraudes no comércio varejista de alimentos, algo que somente a ação dos fiscais do poder público poderia impedir. Alguns médicos preocuparamse com as questões mais diretamente relacionadas ao abastecimento e ao engano a que os consumidores eram induzidos ao fazer suas compras. Era o caso de Samuel Leite Ribeiro, que ressaltou a existência, desde 1893, em São Paulo, de um policiamento da alimentação pública, que incluía a repressão a fraudes e falsificações (RIBEIRO, 1926, p. 24).

Outro sentido possível para a ignorância era o desconhecimento que os profissionais da saúde pública tinham em relação aos hábitos, comportamentos e práticas alimentares da população, por falta de instrumentos seguros que thes permitisse concluir algo diferente do que rezava o senso comum. Os autores Geraldo de Paula Souza, Antônio de Ulhoa Cintra e Pedro de Carvalho, na apresentação dos resultados do inquérito alimentar que coordenaram em 1932, remontaram à idéia, então corrente, de que "no Brasil não há realmente fome e com pouco dinheiro se vive, a generosidade proverbial de nosso povo suprindo a escassez alimentar dos menos favorecidos" (1935, p. 3). Questionavam, assim, essa crença amplamente difundida, que os levara a promover o inquérito com a intenção de aproximar-se da "realidade".

A ignorância que efetivamente interessa aqui, no entanto, tinha um significado diferente e mais amplo no ideário dos intelectuais preocupados com o tema da alimentação na primeira metade do século XX. Tratava-se da ausência de conhecimentos formais - a respeito de quais alimentos seriam mais saudáveis para o consumo individual ou familiar - que pudessem ser verbalizados a contento diante de um profissional da saúde pública. Mais do que as questões de renda, tradições culturais e possibilidades de consumo diante das fontes de abastecimento disponíveis, era essa ignorância que impedia a população de alimentar-se de modo correto - entenda-se correto de acordo com o que era preconizado pela ciência da nutrição naquela época.

○ uso do termo "população", e não "classes populares", é proposital. Afinal, para muitos médicos, cientistas sociais ou nutrólogos do período em questão, a ignorância atingia inclusive as famílias ricas. Nesses casos, a responsabilidade era lançada sobre mães ociosas, que sequer cumpriam seu dever básico de ordenar as tarefas a serem cumpridas pelos empregados. Por vezes, essas mulheres não sabiam nem mesmo alimentar-se de acordo com exigências circunstanciais: na visão de Thalino Botelho, era freqüente ver grávidas de "classes elevadas" consumirem condimentos em excesso junto "com as mais 
exóticas substâncias e a beber os mais estranhos cock-tails!" Evidentemente, ele localizava o problema também em outros meios sociais: o sucedâneo dos "estranhos cock-tails" entre as grávidas das classes populares era a "malfadada cerveja preta domingueira" (BOTELHO, 1955, p. 134-135).

Embora apontado o problema da ignorância também entre os mais favorecidos, fica claro que não era este o cerne da questão da saúde pública. A interpretação de dados estatísticos, aparentemente neutros, não deixava dúvidas sobre qual o tipo de ignorância a ser combatido. Waldemar Luiz Rocha, em trabalho apresentado ao III Congresso Brasileiro de Higiene, lidou com estimativas de mortalidade infantil que, na análise dele, deixavam claro serem as doenças gastrointestinais as responsáveis por muitas mortes nessa faixa etária. Mas esse seria apenas o sinal exterior, pois a mortalidade, no fundo, devia-se "maximamente à ignorância das mães" que não sabiam alimentar seus filhos lapud COLLUCCl, 2001 , p. 81 l), e não a motivos como a pouca eficácia dos serviços de vigilância sanitária nas feiras, nos mercados e no comércio de secos e molhados, ou a qualidade da água distribuída à população - sendo este último um problema identificado em artigo de Souza (1936), por exemplo.

Embora a experiência estrangeira com os inquéritos alimentares fosse valiosa, nas palavras de Souza e Wanderley (1921, p. 3), já era tempo de adaptar e aplicar os métodos de investigação entre as famílias brasileiras. Afinal, tínhamos um "exemplo caseiro" de péssimo regime alimentar: o do "caboclo", especialmente no Nordeste do país, onde o "lirismo de falsos patriotas" encobria "o seu precário estado de nutrição". Esses autores, no entanto, foram bastante cuidadosos em suas afirmações, deixando claro que, se a ignorância levava a deficiências proteínicas e de cálcio, por exemplo, a quantidade de alimentos continuava a ser uma questão pendente. A dieta só não era mais volumosa e rica devido à má distribuição de renda que atingia os "caboclos":

Os recursos de muitos, se adequadamente instruídos, dariam para, substituindo uns alimentos por outros, vencer as dificuldades; para outros, entretanto, impõe-se a providência de maior valia - em higiene, a mais difícil e complexa: a que tende à melhoria do padrão de vida (SOUZA; WANDERLEY, 1921, p. 6-8).

Na tabulação dos dados coletados no inquérito (SOUZA; CINTRA; CARVALHO, 1935 , p. 13-33), sobressaem primeiramente as categorias etárias nas quais foram classificados os inquiridos: crianças até 12 anos e adultos com mais de 12 anos - excluindo-se, portanto, categorias como as que vinham sendo trabalhadas nos textos sobre a alimentação do pré-escolar e do escolar, que se valiam dos conceitos de puberdade e adolescência, considerando as necessidades nutricionais próprias a essas fases da vida.

No inquérito realizado em Cerqueira César e Pinheiros, as informações prestadas por 479 famílias denotam que, pela ordem, os alimentos consumidos pelo maior número de pessoas eram pão, leite, carne, arroz, feijão, massas, batata, ovos e queijo. Legumes e verduras não foram quantificados, em função da dificuldade de anotar o consumo desses produtos nas fichas, quer pela 
11. Um dos primeiros alimentos de largo consumo popular a ser objeto de legislação e políticas públicas. Ver, por exemplo, os Anais da Primeira Conferência Nacional do Leite, reunida em 1925 e promovida pela Sociedade Nacional de Agricultura e pelo governo federal. Rio de Janeiro, Cia. Nacional de Artes Graphicas, 1926. No caso do estado de São Paulo, a Inspetoria de Policiamento da Alimentação Sanitária criada em 1925, concentrou a ação de seus agentes na produção e distribuição do leite; cf. Sandra Regina Collucci $(2001$, p. 26) variedade das escolhas, quer pelas variações nas unidades assinaladas (dúzia, maço, peso etc.).

Tomando uma amostra de 168 fichas familiares, onde constavam dados sobre consumo de pão, leite, feijão e carne, os autores constataram que, quanto maior a renda das famílias, maiores eram as despesas alimentares. Crescendo a renda, crescia também o consumo de carne, enquanto o consumo de pão e leite continuava no mesmo nível e caía o de feijão. Isso levava a deduções que extrapolavam o universo alimentar familiar: "O superavit de dinheiro resultante deste fato seria destinado a outros fins, possivelmente diversos da despesa alimentar" (SOUZA; CINTRA; CARVALHO, 1935, p. 42-44).

Nas conclusões do trabalho, na verificação das deficiências do regime alimentar entre os moradores dos bairros assinalados, a ignorância popular não era tão ressaltada. É fato que os autores do primeiro inquérito alimentar feito em São Paulo estranharam a estabilidade no padrão de consumo do leite" ", mesmo quando a renda familiar permitia comprar o produto em quantidades maiores. Mas também é fato que, se o leite era uma fonte de proteína animal importante, a carne igualmente o era. Neste caso, os autores reconheceram que a deficiência se devia ao custo elevado do produto. Identificado o deficit, propunham soluções aparentemente fora do âmbito de atuação dos profissionais de saúde pública. Entre elas, o desenvolvimento da cultura da soja (com preços e gosto semelhantes ao do feiião consumido amiúde na cidade), e "uma modificação tal no regime industrial e comercial da carne e do leite, que acarretasse sensível barateamento de seu custo, para então poder frutificar a propaganda da intensificação do consumo, e conseguir-se imprimir no povo o hábito do uso de tão úteis alimentos" (SOUZA; CINTRA; CARVALHO, 1935, p. 45-48).

O combate à ignorância popular ganhou outros diagnósticos e argumentos ao longo da primeira metade do século XX. Os debatedores do tema, porém, reconheciam a antiguidade do problema e do próprio debate.

Como afirmou Thalino Botelho, "a ignorância e o pauperismo" eram, havia pelo menos quarenta anos, os motivos clássicos da má alimentação. Pela ordem, primeiro viria o combate ao pauperismo, que ele reconhecia ser o fator mais importante, propondo ampliar a produção de alimentos, melhorar o cultivo da terra e priorizar as condições do transporte. Já a ignorância residual tinha de ser vencida pela educação e dependia de pré-requisitos em políitica econômica e agrícola: "educaríamos o povo ensinando-o a abrir a bolsa para compra dos melhores alimentos, já então produzidos em maior escala, a mais baixo preço" (BOTELHO, 1955, p. 192-193).

O binômio pauperismo-ignorância já fora evocado por Dante Costa, especialista em a limentação escolar. Costa era nutrólogo e professor da Faculdade de Medicina da Universidade do Brasil, no Rio de Janeiro. Organizou a Seção Técnica do Serviço de Alimentação da Previdência Social que, entre outras medidas, criou um serviço de desjejum escolar em 1942, atendendo cerca de mil filhos de trabalhadores que, entre outras contrapartidas, tinham de se submeter a exames médicos em dias agendados. As definições de Costa eram avalizadas oficialmente, não só devido à sua inserção no funcionalismo público, mas também pelo fato de que era o governo federal quem publicava suas obras, como Alimentação e progresso: o problema do Brasil e Higiene, alimentação e crime, 
ambas editadas pelo Serviço de Alimentação da Previdência Social. Em função de sua especialidade, esse autor ressaltava as ações educacionais, realçando o papel de "alguns esplêndidos cursos, em São Paulo", que formavam educadoras sanitárias para desenvolver também atividades ligadas à alimentação em escolas e centros de saúde. No entanto, o principal marco nesse sentido teria sido a formação e o início da atuação das primeiras turmas de visitadoras de alimentação, em 1941, pelo Serviço de Alimentação da Previdência Social:

munidas de endereços de um cadastro previamente obtido, visitavam cada casa durante quatro semanas, uma visita por semana, realizando na sala de jantar e na cozinha familiar uma educação alimentar objetiva e prática, sem eliminar contudo algumas das novas aquisições da educação racional (COSTA, 1951, p. 93).

Alguns de seus métodos poderiam causar certa estranheza entre as donas de casa. Tais métodos envolviam desde a organização de listas de compras a partir das verbas disponíveis pela família até a satisfação das predileções dos moradores da casa e das "verdades da ciência alimentar" (COSTA, 1951, p. 94).

Merenda escolar

As escolas também se apresentavam como espaços privilegiados para a intervenção direta dos especialistas em higiene alimentar, por meio da merenda escolar.

Antes de abordar o tema na primeira metade do século XX, reportome a um debate mais recente. A partir de meados da década de 1980, no bojo de mais uma transição democrática na história política brasileira, educadores e administradores públicos envolveram-se em um acalorado debate. Tratava-se de definir o papel a ser cumprido pelas instituições escolares na solução dos problemas relacionados à desnutrição, educação e pobreza, diante da afirmação de que as escolas estavam se tornando "grandes restaurantes" e, por conseqüência, sendo assistencialistas e adotando soluções paliativas não relacionadas à sua função precípua: o ensino (FISCHMANN, 1986, p. 75).

A abordagem podia ser nova, mas o tema em debate não era novidade. Pelo menos desde meados da década de 1940, a distribuição de merendas escolares já era motivo de discussões e estudos.

Primeiramente, vamos verificar uma definição de merenda escolar. Vejamos a exposição do conceito feita por Dante Costa em 1939:

A merenda é a pequena refeição, de digestão fácil e valor nutritivo bastante, realizada no intervalo da atividade escolar. Ela constitui um dos muitos traços de união entre a casa e a escola: preparada em casa, pelo cuidado solícito das pessoas disso encarregadas, vai ser utilizada na escola. Mais uma vez vê-se que a escola é e deve ser o prolongamento do lar ${ }^{12}$.
12. Cf. Dante Costa (1939, p. 5). Em seu manual destinado às mães e às jovens estudantes, Isabel Serrano (1951, p. 130-138), reproduziu as sugestões de merenda escolar de Dante Costa, o que denota a popularidade e a longevidade da proposta. 
A merenda teria a função social de minorar os problemas nutricionais entre as crianças, num quadro em que era de "domínio público que o nosso povo come mal, de maneira desacertada e deficiente" (COSTA, 1939, p. 3). No caso das crianças, a desnutrição era entendida como um dos motivos do mau rendimento escolar - mas não o único, já que a ela deveriam se somar as condições habitacionais, de vida familiar e a hereditariedade (COSTA, 1948, p. 13). Para corrigir o que lhe competia como intelectual e servidor público, Costa sugeriu cardápios a serem trazidos de casa, compostos basicamente de leite, sucos de frutas, bolos, polenta, tapioca, chocolate e sanduíches feitos de ovos, de carne de boi e de galinha, requeijão e queijo.

Elaborada em fins da década de 1930, essa concepção de merenda escolar soa estranha à sensibilidade dos cidadãos do século XX́. Por merenda, o autor definia aquele alimento trazido da casa para a escola e consumido nesta última, e não, como passou a se fazer mais tarde, o alimento oferecido pelas diferentes instâncias de governo nas escolas mantidas com dinheiro público. No entendimento do percurso entre uma e outra forma de merenda, o debate sobre - assistencialismo na rede escolar, que oferta comida como um "grande restaurante" a partir da década de 1980, torna-se mais compreensível.

A preocupação de Costa era orientar as mães no preparo da merenda. A sistematização dessas orientações consolidou-se após a realização de inquéritos alimentares em boa parte do território brasileiro, entre as décadas de 1930 e 1940, a fim de definir hábitos e comportamentos alimentares calcados nas condições regionais do país. Cerca de dez anos depois, a preocupação já se deslocara: a merenda começava a ser vista como refeição feita e preparada na escola. A transformação originara-se nas próprias mudanças das políticas públicas, neste caso voltadas à chamada "assistência alimentar ao escolar". As opções vislumbradas para materializar essa assistência eram a oferta de desjejuns, almoços ou merendas, tendo o poder público optado, na maioria das vezes, pela terceira possibilidade. Como afirmava Costa, algumas escolas já serviam o almoço escolar, mas essa era uma medida de difícil implementação econômica (COSTA, 1948, p. 13).

A propaganda da Prefeitura paulistana sobre a importância dos parques infantis resultou em inúmeras publicações sobre as iniciativas educacionais no município, destacando a atenção dada à "assistência alimentar" oferecida nesses parques, com o objetivo de sanar a desnutrição. Pesquisas do Serviço de Higiene Escolar do Estado davam conta de que $60 \%$ das crianças matriculadas nos parques infantis eram desnutridas. Esse cálculo valeria não apenas para o público dos parques, mas para a "criança proletária" em geral, quase sempre portadora de duas ou três doenças, muitas das quais poderiam ser sanadas com uma alimentação adequada. Para poderem cumprir os programas de jogos e educação física, as crianças tinham de ser alimentadas em um patamar mínimo e, para tanto, a prefeitura instituiu a merenda escolar, "com fornecimento de frutas, doces, pão, queijo e leite, atingindo este a 30 mil copos mensais" (MIRANDA, 1938, p. 20; 1941, p. 20) (Figuras 16 e 17). 

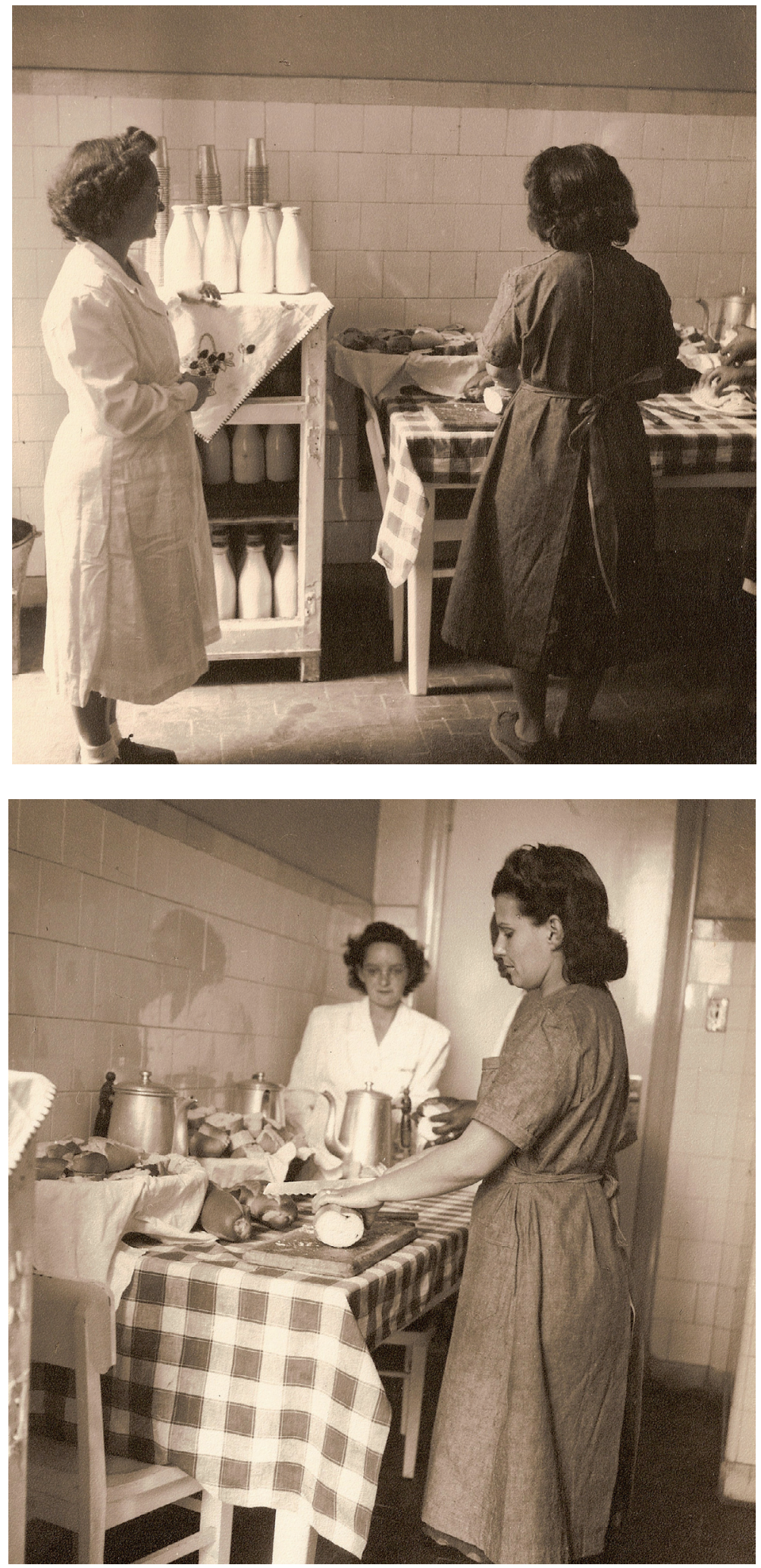

Figura 16 - Ao passar a ser preparada nas cozinhas das escolas, a merenda escolar tornouse mais um dos objetos de interesse e intervenção das educadoras sanitárias. Nas imagens, feitas entre meados dos anos 1930 e meados da década seguinte, podemos observar alguns aspectos do olhar investigador das educadoras. Verificação do acondicionamento do material alimentício no Parque Infantil Barra Funda. Imagem n. 1737, sem título, sem data, s.n.p. Acervo do Centro de Memória da Saúde Pública, Faculdade da Saúde Pública da USP, São Paulo.
Figura 17 - Inspeção do preparo de alimento no Parque Infantil Barra Funda. Imagem n. 1743, sem título, sem data, s.n.p. Acervo do Centro de Memória da Saúde Pública, Faculdade da Saúde Pública da USP, São Paulo. 
Simultaneamente, o estado e o município de São Paulo também desenvolveram, ainda que de forma irregular, programas de complementação alimentar destinados às crianças, em particular aos escolares. Mencione-se, nesse sentido, os programas de distribuição de leite in natura e em pó que, com diversas denominações, foram implantados desde 1945 e vigoram até hoje (CAVALCANTI; RIBEIRO, 2003, p. 35).

Alimentação dos operários

No conjunto de moradores da cidade, além dos escolares e das famílias, os trabalhadores fabris representaram o terceiro recorte a respeito do qual foram produzidos discursos técnicos, pensadas políticas específicas e exercida a atividade daqueles profissionais que se dedicavam aos temas da alimentação. Podem ser apontadas algumas especificidades desses discursos, práticas e políticas.

Destaco, primeiramente, a atenção relativamente tardia de atuações e produções intelectuais, quando a questão da alimentação dos operários é comparada à dos escolares ou à das famílias. É certo que questões como a ignorância e seu contraponto - a "alimentação racional" - também foram aplicadas como diagnósticos e conceitos de intervenção acerca da realidade alimentar dos operários, mas se referiam de forma ampla a toda a população urbana.

A segunda especificidade da alimentação dos trabalhadores fabris que quero destacar é a relativa isenção dos poderes públicos ou, dito de outro modo, o papel desempenhado pela parceria desses poderes com a iniciativa privada - especialmente com os industriais e seus representantes em entidades de classe patronais. Inquéritos alimentares voltados ao público familiar, particularmente de famílias de trabalhadores (ainda que nem todos fossem operários), foram aplicados em São Paulo desde 1932; e diferentes políticas de saúde tomaram essas experiências como base. A criação do salário mínimo também pode ser entendida como uma medida que alcançava as famílias, já que era voltada aos trabalhadores urbanos e pensada enquanto possibilidade de satisfação das necessidades básicas das famílias destes. Diferentemente das escolas ou dos parques infantis, que eram espaços notoriamente públicos, os operários reuniam-se em espaços privados, sob a responsabilidade dos empregadores - e, no caso da alimentação, sob sua própria responsabilidade.

Foram diversos os autores interessados na alimentação dos operários. Alguns aplicaram inquéritos ou valeram-se dos resultados de inquéritos aplicados por outrem, como Oscar Egídio de Araújo (1940, p. 91 - 1 16). Outros se detiveram nas variações de necessidades alimentares em função da ocupação, como Josué de Castro (1935) e Thalino Botelho (1955). No Instituto de Higiene, o professor Benjamim Alves Ribeiro levava em conta esses dois aspectos, considerando as recomendações da Junta de Higiene da Liga das Nações, que definia as 
necessidades calóricas de acordo com o sexo, com o exercício muscular, o clima em que se vivia, a idade e a condição de grávidas e nutrizes. Suas equações consideravam todas essas variáveis - como no exemplo, retirado do trabalho do médico e nutricionista estadunidense James Somerville Mclester (1 877-1954), que previa a necessidade total em calorias "dum sapateiro de 40 anos de idade, $180 \mathrm{~cm}$ de altura e 70 quilos de peso, trabalhando oito horas por dia" (RIBEIRO, 1938, p. 5).

As preocupações de Ribeiro ampliaram-se para abarcar a saúde dos trabalhadores no ambiente das fábricas. Na década de 1940, a Seção de Higiene do Trabalho do Instituto de Higiene projetou o serviço médico do Instituto de Pesquisas Tecnológicas (IPT) - naquela altura uma instituição anexa à Escola Politécnica da USP, empregando 250 pessoas, entre técnicos, pessoal administrativo e operários. Na ficha de exames médicos periódicos, os trabalhadores deveriam informar seus hábitos alimentares, o que se traduzia em inquéritos feitos regularmente no interior de um mesmo grupo. Os médicos deveriam indagar quantas eram as principais refeições do dia, onde e quanto os trabalhadores comiam, se bebiam (leite e café, mas também álcool) ou fumavam, e qual era a freqüência de suas evacuações intestinais (RIBEIRO, 1943 , p. 3-8).

O IPT era um dos poucos estabelecimentos industriais paulistanos onde os trabalhadores contavam com restaurantes - experiência que vinha sendo timidamente introduzida no país havia alguns anos. Cleto Veloso, por exemplo, fez uma alusão rápida à necessidade de se criarem restaurantes populares e cozinhas coletivas em fábricas, quartéis, colégios e hospitais, pois isso garantiria boa alimentação a preços reduzidos (VELOSO, 1940, p. 364) - não sabemos se do mesmo tipo previsto por seu contemporâneo Bannitz (1942): peso e altura seriam tomados à entrada dos restaurantes e os pratos seriam postos à mesa de acordo com as medidas do consumidor.

Dante Costa iria mais longe, mas somente no início da década seguinte - quando traçaria um breve apanhado histórico sobre o surgimento dos restaurantes populares na União Soviética e o sucesso da experiência conduzida pelo Serviço de Alimentação da Previdência Social com esses restaurantes. Costa não informou quantos restaurantes eram mantidos pelo Saps, mas sabemos que, até aquela data, havia estabelecimentos dessa natureza apenas na capital federal, e planejava-se instalar mais 198 em cinco anos, distribuídos entre capitais como Rio de Janeiro, São Paulo, Recife, Salvador e Porto Alegre. De acordo com ele, havia dois tipos de restaurantes populares: os que serviam cardápios fixos e os que não os serviam, com vantagem acentuada para os do primeiro tipo, já que, em países da América Latina, "é baixa a capacidade do povo em escolher adequadamente os alimentos" (COSTA, 1951, p. 53-59).

Os discursos a respeito da alimentação dos operários baseavam-se em estudos abordando necessidades calóricas e, também, em inquéritos e pesquisas de padrão de vida, a partir de exigências ditadas pelo texto da Constituição de 1937 acerca do "problema alimentar da classe obreira" (ARAÚJO, 1940, p. 95). 
Araújo dedicou-se a definir os problemas da alimentação dos operários em São Paulo, partindo de experiências anteriores, como o clássico inquérito de Souza, Cintra e Carvalho e as pesquisas de Horace Davis e Samuel Lowrie - frutos de parcerias entre o Instituto de Higiene, a Escola Livre de Sociologia e Política, e a Prefeitura Municipal. A novidade trazida por seus estudos foi a atenção dada ao fator nacionalidade nos hábitos e comportamentos alimentares. Constatando que a população da cidade era composta por grupos de origens nacionais bastante diferenciadas, Araújo percebeu as diferenças que essas origens traziam para o consumo, os hábitos, os comportamentos e as práticas alimentares, anotando a importância desse fator e a complexidade das questões alimentares no município. De acordo com ele,

a. brasileiros consumiam mais açúcar, arroz e feiião; e menos pão, batata e leite;

b. portugueses e italianos aproximavam-se de brasileiros na média de consumo da maior parte dos alimentos, mas os primeiros destacavam-se no consumo de batata, bacalhau e farinha de trigo, enquanto os segundos, em macarrão, com pouco consumo de batata e peixe;

c. os espanhóis destacavam-se pelo consumo de pão, gordura, tomate, batata e leite, e pouca farinha de trigo;

d. por fim, os lituanos eram grandes consumidores de carne de vaca, batatas, peixe, farinha de trigo, queijo e manteiga, pouco consumindo arroz, feijão e macarrão (ARAÚjO, 1940, p. 99-1011.

Para sanar deficiências nutricionais, monocordicamente atribuídas à ignorância, voltava-se ao tema da educação, posto que "já há salário razoável, capaz de satisfazer, em determinada época e região do país, as necessidades normais de alimentação, habitação, vestuário, higiene e transporte do trabalhador adulto" (ARAÚJO, 1940, p. 110). Mas educar não era tudo: a criação de restaurantes populares pelos industriais, em parceria com o Estado, também estava entre as providências indispensáveis - como já fazia a General Motors, que oferecia (e cobrava) refeições em sua fábrica situada em São Caetano do Sul. Araújo sugeria ainda retomar a "idéia muito interessante" de Paula Souza, que eram as cozinhas populares, onde seriam preparados e vendidos alimentos básicos e em rações exatas (ARAÚjO, 1940, p. 111 1).

Outro inquérito com intenções similares foi conduzido no início da década de 1940, por Maria Thereza Nogueira Garcez, assistente social e pesquisadora da Divisão de Estatística e Documentação Social da prefeitura paulistana. Em seu trabalho, podemos ver sinais claros de emprego da metodologia usada nas pesquisas de padrão de vida aplicadas desde 1937 por aquele órgão. Porém a assistente social manifestou outros interesses que podem nos aproximar do universo, ainda bastante desconhecido, que é a alimentação dos operários no período.

Uma vez consolidado seu questionário, a autora o aplicou entre 330 trabalhadores fabris, moradores de 22 bairros da capital e de dois municípios vizinhos, a maioria deles áreas de concentração operária: Água Rasa, Tatuapé, Belém, Brás, Vila Maria, Mooca, Ipiranga, Vila Anastácio, Vila Prudente, Vila 
Bela, Vila Zelina, Vila Leopoldina, Cambuci, Lapa, Pinheiros, Perdizes, Casa Verde, Jardim Paulista, Vila Mariana, Liberdade, Itaquera, Artur Alvim, Santo André e São Caetano do Sul (GARCEZ, 1943, p. 9-10).

No grupo, mais de $80 \%$ dos entrevistados alimentavam-se no trabalho, mas nenhuma das indústrias que empregavam esses operários dispunha de instalações como restaurantes ou cozinhas: "a alimentação ele [o operário] a traz consigo ao vir para o trabalho, o que é mais freqüente, ou recebe de casa à hora do almoço". No interior da fábrica, sequer havia refeitórios ou outros espaços, para serem usados na hora das refeições, pois os operários almoçam, "na maior parte das vezes, desabrigados, em péssimas condições higiênicas e sem o menor conforto (sentados pelas sarjetas, sem água para lavar as mãos, estirados ao longo das calçadas" (GARCEZ, 1943, p. 35-44). A situação apontada por Garcez assemelhava-se àquela constatada alguns anos antes por Paula Souza:

A classe trabalhadora ou se nutre do que leva de casa, nem sempre alimento mais apropriado, ou recorre ao restaurante barato, onde as mais das vezes só pode controlar a quantidade fornecida, nada sabendo quanto à qualidade e à maneira de preparo; gêneros impróprios, que desafiam a arte do cozinheiro, constituem freqüentemente o prato dessa gente ${ }^{13}$.

Garcez insistia na ignorância como um aspecto dos problemas alimentares, ao constatar a reduzida variedade dos cardápios das marmitas (arroz, feijão e carne; ou feijão e arroz combinados a alimentos como lingüiça, batata, banana e polenta) ${ }^{14}$. Mas, como agravante desses mesmos problemas, indicava também a péssima situação econômica; e via nos restaurante populares a solução, pois estes ofereceriam refeições sadias e "racionalmente dosadas", além de estarem localizados nas próprias fábricas - quando estas comportassem - ou em locais que permitissem atender trabalhadores de mais de uma fábrica.

As autoridades estaduais orientariam a implementação, pois quem deveria dirigir tais restaurantes era a iniciativa privada. Sua concepção aproximava-se de um discurso mais recente sobre o papel do Estado na economia, mas pode soar familiar também àqueles que, hoje, identificam a suposta ineficiência estatal também na área social:

[Os restaurantes seriam] preferencialmente de iniciativa particular, uma vez que, apenas secundariamente, o Estado é chamado a exercer sua função social - pois sempre que um indivíduo ou empresa particular, sem ferir direitos alheios, puder agir a bem de seus próprios interesses, da mesma maneira que o Estado faria diretamente, este deve abster-se sistematicamente de intervir (GARCEZ, 1943, p. 45).

A presença estatal seria sentida na educação a limentar, embora mesmo nesse nível os empregadores tivessem um papel a cumprir junto aos "membros da família operária". Os industriais, "porção mais favorecida no rebanho de Nosso Senhor Jesus Cristo", não se davam conta de seu "dever de caridade" para com os operários e esqueciam-se de que eram "homens intelectualmente mais desenvolvidos que os seus dirigidos" (GARCEZ, 1943, p. 48).
13. Ver Jaime Rodrigues (2006), doc. PI 1939.2, 8 fev.1939, fls. 1 e 2 (texto escrito para o Jornal da Ma$n h \tilde{a})$.

14. Constatação próxima à da análise comparativa de Oscar Araújo (1940, p. 92) acerca da alimentação básica dos paulistanos, constituída de feijão, batata, pão, arroz e carne. 
Seja na forma de intervenções técnico-científicas ou na de elaboração e implementação de políticas públicas, a alimentação popular em São Paulo foi um objeto sobre o qual os profissionais da saúde pública se debruçaram desde os primeiros passos na direção de uma consolidação institucional. Foi também sobre esse objeto que a ciência da nutrição pôde delimitar seus interesses acadêmicos e consolidar-se como um discurso competente a respeito das práticas, hábitos e comportamentos dos populares, buscando e logrando certa autonomia em relação às ciências médicas, biológicas e sociais.

A sociedade na qual esses profissionais intervieram não cessou de se transformar ao longo do período estudado. Parte dessas transformações podem ser creditadas à própria intervenção estatal e acadêmica, mas o universo das mudanças não estava, absolutamente, restrito a essas ações. Descartando qualquer tipo de determinismo ou onipotência na atuação de cientistas e poderes públicos no que tange aos hábitos e comportamentos sociais, não se pode negar a eficácia das pretensões de se corrigir problemas pela via da educação, mesmo que por um viés por vezes autoritário. Se os principais efeitos de uma política educacional alimentar somente se fariam sentir nas gerações futuras, faziam-se necessárias outras ações, mediante diagnósticos da sociedade: a aplicação de inquéritos alimentares e a delimitação de seu respectivo público-alvo reiteraram o conceito da ignorância popular em relação à sua própria alimentação. $\bigcirc$ combate à ignorância só poderia ser feito recorrendo-se ao seu oposto: a racionalidade. A disseminação da idéia de "alimentação racional" como base de políticas públicas na área rendeu inúmeras páginas em estudos feitos principalmente durante o Estado Novo - tema que ainda se ressente de uma análise mais detida pelos historiadores da alimentação no Brasil.

\section{FONTES}

\section{CMSP / FACULDADE DE SAUDE PÚBLICA / USP}

\section{Documentos do Arquivo Geraldo Horácio de Paula Souza}

MI s/d 24 - Orientações sobre os trabalhos que os alunos deveriam elaborar para a disciplina de Técnica Sanitária, sem data.

MI 1925.5 - Documento organizado pela Fundação Rockfeller, apresentando os membros associados e suas respectivas áreas de estudos em várias partes do mundo, dez.1925.

PI 1926.2A e B - Esquema utilizado para inspeção sanitária: topografia, meteorologia, população, estatística vital, administração pública, serviços sanitários, recursos contra doenças. Atividades para inquérito: água, dejetos, lixos e resíduos, moscas, mosquitos, leite, outros alimentos e habitações, sem data. 
PI 1939.2 - Artigo para o Jornal da Manhã.Aponta a questão alimentar no Brasil como problema econômico e educativo. Sugere que o Ministério da Previdência Social e Higiene Pública buscasse colocar em prática os restaurantes populares para disponibilizar à população pobre alimentos baratos e sadios, 8 fev. 1939.

\section{Manuscritos avulsos}

Livro de Assinaturas do VII Congresso Brasileiro de Higiene. São Paulo, 1948.

Fotografias

Álbum n ${ }^{\circ} 4$ - Vistas de São Paulo e do Instituto de Higiene, década de 1920.

Imagem no 1722 - Educação sanitária, Grupo Escolar Regente Feijó, 9 de novembro de 1925.

Imagem $n^{\circ} 1737$ - Verificação do acondicionamento do material alimentício no Parque Infantil "Barra Funda", sem data.

Imagem n 1743 - Inspeção do preparo de alimento no Parque Infantil "Barra Funda", sem data. Imagem $\mathrm{n}^{\circ} 1751$ - Alunos desnutridos (20\% abaixo da tabela do Dr.Vieira de Mello), sem data.

Imagem no 1792 - Educação em saúde na Escola Prudente de Morais, 1925.

Imagem $n^{\circ} 1859$ - Charge sobre o curso de médicos nutrólogos do Instituto de Nutrição da Universidade do Brasil, sem data.

\section{Legislação}

Decreto $\mathrm{n}^{\circ} 10.617$, de 24 de outubro de 1939.

Decreto $\mathrm{n}^{\circ}$ 15.549-A, de 15 de janeiro de 1946.

Decreto $\mathrm{n}^{\circ} 15.552$, de 24 de janeiro de 1946.

Decreto $\mathrm{n}^{\circ} 15.553$, de 24 de janeiro de 1946.

\section{CENTRO DE INFORMAÇÃO E REFERÊNCIA, FACULDADE DE SAÚDE PÚBLICA-USP}

\section{Impressos: livros, periódicos e outros}

ALMEIDA JÚNIOR,A.Alimentação na idade escolar e pré-escolar. Boletim do Instituto de Higiene, São Paulo, v. 15, 1923 a.

ALMEIDA JÚNIOR,A. Cartilba de higiene para uso das escolas primárias. São Paulo: Instituto de Higiene, $1923 \mathrm{~b}$. 
ANAIS da Primeira Conferência Nacional do Leite. Rio de Janeiro: Companhia Nacional de Artes Graphicas, 1926a.

ANAIS do Primeiro Congresso Brasileiro de Higiene, v. 1: Sessão inaugural e temas oficiais. Rio de Janeiro: Oficina Gráfica da Inspetoria de Demografia Sanitária, 1926b.

ARAÚJO, Oscar Egídio de. A alimentação da classe obreira de São Paulo. Revista do Arquivo Municipal de São Paulo, São Paulo, v. 69, p. 91-116, ago.1940.

BANNITZ, Joaquim Novais. Centro de saúde, contendo novidades sobre alimentação nos colégios, asilos, orfanatos etc. 2. ${ }^{a}$ ed. São Paulo: Mangione, 1942.

BOTELHO, Thalino. Os pequenos fundamentos da boa alimentação. Rio de Janeiro: Serviço de Propaganda e Educação Sanitária, 1938.

BOTELHO,Thalino. Acesso à alimentação racional. 2. ${ }^{\mathrm{a}}$ ed. Rio de Janeiro: [s.e.], 1955.

CONGRESSO BRASILEIRO DE HIGIENE, 7. 1948, São Paulo, Programa.

COSTA, Dante. Alimentação do escolar. Rio de Janeiro: Serviço de Documentação do Ministério da Educação e Saúde; Imprensa Nacional, 1948.

. Alimentação e progresso: o problema do Brasil. Rio de Janeiro: Saps, 1951.

. Merendas escolares: vinte e cinco sugestões de merendas para crianças escolares brasileiras. Rio de Janeiro, Serviço Gráfico do MEC, 1939.

GARCEZ, Maria Thereza Nogueira. Inquérito das condições de alimentação entre um grupo de operários da capital. 1943. Monografia (Conclusão de Curso de Assistência Social) - Curso de Assistência Social da Pontifícia Universidade Católica de São Paulo, São Paulo, 1943.

IBGE. Repertório estatístico do Brasil, quadros retrospectivos. Rio de Janeiro: Instituto Brasileiro de Geografia e Estatística, 1986 (Estatísticas retrospectivas, I).

LOWRIE, Samuel H. Origem da população da cidade de São Paulo e diferenciação das classes sociais. Revista do Arquivo Municipal de São Paulo, São Paulo, v. 43, p. 195-212, jan.1938.

MASCARENHAS, Rodolfo dos Santos; FREITAS, Adélia V. Contribuição ao estudo da história do ensino de educação sanitária na Faculdade de Higiene e Saúde Pública da Universidade de São Paulo. Arquivos da Faculdade de Higiene e Saúde Pública da Universidade de São Paulo, São Paulo, v. 13, n. 1, p. 243-262, jun.1959.

MIRANDA, Nicanor. O significado de um parque infantil em Santo Amaro. São Paulo: Subprefeitura de Santo Amaro, 1938.

. Origem e propagação dos parques infantis e parques de jogos. São Paulo: Departamento de Cultura, 1941. 
RIBEIRO, Benjamim Alves. Organização e funcionamento de um serviço médico industrial. Boletim do Instituto de Higiene de São Paulo, São Paulo, n. 80, 1943.

. Princípios da alimentação do homem normal. Boletim do Instituto de Higiene de São Paulo, n. 63, 1938.

RIBEIRO, Samuel Leite. A fiscalização sanitária dos gêneros alimentícios no Estado de São Paulo. São Paulo: Faculdade de Medicina de São Paulo, 1926.

SERRANO, Isabel. Noções de economia doméstica (de acordo com os programas para o Curso Ginasial do Ensino Secundário). São Paulo: Nacional, 1951.

SOUZA, Geraldo Horácio de Paula.Aspectos do problema da água de alimentação em São Paulo. Arquivos de Higiene e Saúde Pública, São Paulo, v. 1, n. 2, p. 109-124, dez.1936.

SOUZA, Geraldo Horácio de Paula e WANDERLEY, L.A. Ensaios de calorimetria alimentar. Boletim do Instituto de Higiene, n. 6, 1921.

SOUZA, Geraldo Horácio de Paula; CINTRA, Antônio de Ulhoa; CARVALHO, Pedro Egídio de. Inquérito sobre alimentação popular em um bairro de São Paulo. Separata de:Boletim do Instituto de Higiene, n. 58, 1935 [reed.: 1944].

VELOSO, Cleto. Alimentação: o problema da alimentação encarado do ponto de vista fisiológico, higiênico, dietético e social. Rio de Janeiro: Zélio Valverde, 1940.

\section{REFERÊNCIAS}

\section{Impressas}

ALVES, Edgard Luiz Gutierrez. Nível alimentar, renda e educação. Estudos Econômicos, São Paulo, v. 7, n. 2, p. 111-146, 1977.

ARANTES,AntonioA.Paisagens paulistanas: transformações do espaço público. Campinas: Editora da Unicamp; São Paulo: Imesp, 2000.

BARELLI, Walter; ALVES, Edgard Luiz Gutierrez; MARTINI, Virgínia Glória Lopes de. Perfil do consumo alimentar da classe trabalhadora. Pesquisa \& Debate, São Paulo, v. 1, n. 6, p. 71-87, set. 1989.

BELIK, Walter. Perspectivas para segurança alimentar e nutricional no Brasil. Saúde e Sociedade, São Paulo, v. 12, n. 1, p. 12-20, jan.-jun. 2003.

CAMPOS, Cristina. São Paulo pela lente da bigiene: as propostas de Geraldo Horácio de Paula Souza para a cidade, 1925-1945. São Paulo: Rima; Fapesp, 2001. 
CAVALCANTI, Nicanor Ferreira \& RIBEIRO, Helena. Condições socioeconômicas, programas de complementação alimentar e mortalidade infantil no Estado de São Paulo (1950 a 2000). Saúde e Sociedade, São Paulo, v. 12, n. 1, p. 31-42, jan.-jun. 2003.

COLLUCCI. Sandra Regina. Mães, médicos e charlatães: configurações culturais e múltiplas representações dos discursos médico-sanitaristas (São Paulo, 1920-1930). 2001. Dissertação (Mestrado em História) - Pontifícia Universidade Católica de São Paulo, São Paulo, 2001.

COSTA, Jurandir Freire. Ordem médica e norma familiar. Rio de Janeiro: Graal, 1979.

DIEZ GARCIA, Rosa Wanda. A comida, a dieta, o gosto: mudanças na cultura alimentar urbana. São Paulo: Instituto de Psicologia da Universidade de São Paulo, 1999.

FISCHMANN, Roseli. Educação, alimentação e economia: uma relação de coerência ou contradição? Educação e Sociedade, São Paulo, v. 8, n. 24, p. 75-98, ago. 1986.

GRANGEIRO, Cândido Domingues. As artes de um negócio: a febre photographica (São Paulo, 1862-1886). Campinas: Mercado de Letras; São Paulo: Fapesp, 2000.

LIMA, Claudia. Tachos e panelas: historiografia da alimentação brasileira. Recife: edição da autora, 1999.

LIMA, Eronides da Silva. Gênese e constituição da educação alimentar: a instauração da norma. 1997. Tese (Doutorado em Educação) - Pontifícia Universidade Católica de São Paulo, São Paulo, 1997.

LORIMER, Rosemeire B. O impacto dos primeiros séculos de bistória da América na formação da brasilidade alimentar.2001.Tese (Doutorado em Saúde Pública) - Faculdade de Saúde Pública da Universidade de São Paulo, São Paulo, 2001.

MENESES, Ulpiano Toledo Bezerra de; CARNEIRO, Henrique de S.A história da alimentação: balizas historiográficas. Anais do Museu Paulista, v. 5, p. 9-91, 1997.

PEIRÃO, Maria Elizabeth et al.Arquitetura escolar paulista: 1890-1920. São Paulo: FDE, 1991.

RODRIGUES, Jaime. Inventário analítico do Arquivo Geraldo Horácio de Paula Souza. São Paulo: Faculdade de Saúde Pública da Universidade de São Paulo, 2006.

RODRIGUES, Jaime;VASCONCELLOS, Maria da Penha Costa.A fotografia como instrumento do trabalho do higienista (São Paulo, primeira metade do século XX). História, Ciências, Saúde, Manguinhos, Rio de Janeiro v. 13, n. 2, p. 477-491, abr.-jun. 2006.

SANTOS, Carlos Roberto Antunes dos.A alimentação e seu lugar na História: os tempos da memória gustativa. História: Questões \& Debates, Curitiba, v. 22 n. 42, p. 11-31, jan.-jun. 2005.

SAÚDE e Sociedade: Fome, Pobreza e Saúde Pública, São Paulo, v. 12, n. 1, jan.-jun. 2003. 
LORIMER, Rosemeire B. O impacto dos primeiros séculos de bistória da América na formação da brasilidade alimentar. 2001.Tese (Doutorado em Saúde Pública) - Faculdade de Saúde Pública da Universidade de São Paulo, São Paulo, 2001.

TAKASU, Sueli K. Sabores brasileiros: o Brasil colonial à mesa. 2000. Dissertação (Mestrado em Saúde Pública) - São Paulo, Faculdade de Saúde Pública da Universidade de São Paulo, São Paulo, 2000.

VASCONCELLOS, Maria da Penha Costa (Coord.). Memórias da saúde pública: a fotografia como testemunha. São Paulo: Hucitec;Abrasco, 1995.

Páginas eletrônicas

BRASIL, Ministério do Desenvolvimento Social. <http://www.mds.gov.br/secretarias/secre taria01_33.asp>.Acesso em: 11 set. 2006.

COMMEMORATIVE address by professor M. Cépède, Independent Chairman of the FAO Council. Disponível em:<http://www.fao.org/docrep/x5591E/x5591e0a.htm>.Acesso em: 11 set. 2006.

VICENTINI, Paula Perin. Celebração e visibilidade: o Dia do Professor e diferentes imagens da profissão docente no Brasil (1933-63). Disponível em: <http://www.anped.org.br/26/trabalhos/ paulaperinvicentni.rtf>.Acesso em: 11 set.2006.

Artigo apresentado em 10/2006. Aprovado em 5/2007. 